\title{
Pain Infliction, Inflictors and Healers in Egyptian Religious, Magical and Literary Perceptions
}

\author{
AMgad JosePH
}

\begin{abstract}
This paper aims at discussing the aetiology, etymology, characteristics and phraseology of pain feeling, infliction and healing in ancient Egyptian religious, magical and literary texts. It examines the roles of the inflictors of pain and their effect on those who were vulnerable to their infliction. It also discusses the roles of the pain healers. Furthermore, it explains the notion of pain infliction and analyses the types of pain, revealing its experience in ancient Egypt. It discusses how it felt, was conceptualised, generated, assessed, how deities, demons, dead and living individuals inflicted and healed it. In relevant contexts, it discusses the places where pain was inflicted and the consequences of such infliction.
\end{abstract}

Keywords: ancient Egypt, pain, religious texts, magical texts, medical texts, literary texts Amgad Joseph, Faculty of Tourism and Hotel Management, Helwan University, Cairo; amgadjoseph@yahoo.com

Pain is associated with an unpleasant sensation. It is an inevitable feeling, which alerts awareness and forms an essential part of human memories. Pain moulds humans' personalities; it defines their lives and sometimes ruins them. It has negative reinforcements associated with painful sensory perceptions that shape human behavioural patterns. Pain is difficult to ignore, it is a unique sensory and ubiquitous emotional experience far more complex and enigmatic than a simple physical alarm system with its protective perception. In ancient Egypt, pain was an obsession of religion, literature and medicine. It had various remedies, ${ }^{1}$ and a variety of aspects like pain of diseases, chronic, instantaneous, emotional, and the pain which is inflicted by the deities, demons, dead and living individuals.

There is a close association between pain on the one hand, and misery, despair, depression, helplessness, and the intervention of deities, dead and living on the other. In this context, the paper analyses the motivations of pain infliction, and the characteristics of the

\footnotetext{
${ }^{1}$ Different remedies are prescribed in medical papyri to alleviate pain; some are complicated while others are simple. One remedy requires only spit on the inflicted organ to ease its pain; see: Borghouts 1978: 35 . For a remedy of freedom from pain ( $h r f m \breve{w} w n n t$ ), see: H.O. 97, 1, 1 [D. 20]; Hoch 1994: 215, n. 13; see also: P. Ebers 242 (46, 10-16); Ghalioungui 1987: 81.
} 
healers and inflictors. The conception of pain in ancient Egypt helps to visualise its effect and the way in which it was inflicted. Pain can be a divine infliction and punishment for people's transgressions and offences. In its emotional perception, it can be assessed through communications and interactions with deities, demons, as well as living and dead individuals. Therefore, pain was known to the Egyptians through experience and interactions, which generate unpleasant feelings.

This article raises the debatable hypothesis as to whether the interaction of factors modulating pain is allied to the variety of psychological, social, religious and physical aetiologies or to other aetiologies. Examination of the attestations of pain feelings, inflictions and healing of each of these aetiologies, as pain stimulations, should provide information on the core and conceptualisation of pain. The paper demonstrates the phraseology of pain in the ancient Egyptian texts dating from the Old Kingdom to the end of the Late period with only one attestation from the Ptolemaic period.

The theme of pain in ancient Egypt raises many questions, namely: Who are the inflictors and subjects of pain? What are the aetiologies and stimulations of pain? What are the words for pain in the Egyptian language? How do they differ from each other? Is there any phraseology of pain in the texts? What are the differences between the pain feelings of humans and those of the deities?

\section{AETIOLOGY OF PAIN}

The discussion of the aetiology of pain aims at examining its conceptualisation, effect and consequences on deities, humans and the deceased. In this respect, it is important to assess objectively whether pain is psychological, physical, caused by a supernatural divine power or inconvenient social circumstances. Examination of these aetiologies, analysis and discussion of their contexts are crucial for the study of pain in ancient Egypt.

\section{Psychological Aetiology of PAIN}

\section{PAIN FEELING}

The heart of humans can suffer feelings of psychological pain. In spell 655 of the Coffin Texts, the deceased is addressed, reading: The obstacles are opened up and the darkness is lightened; may you go out into the day, may [you] have power over your foes, may you have news about those whose hearts are painful ( $3 \mathrm{hw} \mathrm{jbw).}{ }^{2}$ In spell 53 of the Coffin Texts, Isis speaks of her dead husband Osiris, and laments his absence saying: I give orders to(?) (the women) who are at the Great Hall, who are painful at heart (mrwt jb) because of their husbands: Come let us lament Osiris since he is far from us. ${ }^{3}$

In the New Kingdom Lamentations of Khakheprre-soneb, a brave heart amid pain (jb qn $m$ st qsnt) is a companion for its lord. ${ }^{4}$ In the Middle Kingdom Tale of Sinuhe, the

${ }^{2}$ CT VI, 276a-c [655]; Nyord 2009: 92, 106; Carrier 2004b: 1492.

${ }^{3}$ CT I, 242e [53]; Carrier 2004a: 128-129; Faulkner 1973: 52.

${ }^{4}$ Parkinson 1997a: 147. 
hearts of people are painful for him. Thus, he says: Women were chattering anxiously, every heart being painful for me ( $j b \mathrm{nb} \operatorname{mr}(w) n=j$ ), stating 'Is there another warrior who can fight with him?'. ${ }^{5}$ On the other hand, the heart of Sinuhe is itself experiencing pain, since being exiled from Egypt, leading Sinuhe to invoke direct intervention from the god. $\mathrm{He}$ asks: May the god give me peace and act in this way to make a good ending for the one whom he had made helpless, his heart ${ }^{6}$ being painful $(j b=f m r(w))$ for the one whom he has exiled to live in a foreign country. ${ }^{7}$ It is evident that Sinuhe invokes a god to intervene and make a good ending for him.

In the Middle Kingdom Lamentation of Sasobek (Papyrus Ramesseum I), he expresses his laments and psychological pains, while imprisoned in a cell. Thus, he is described as the one who is in pain on earth (nty $m m n w^{8} t p t 3$ ). ${ }^{9}$ In a Ramesside letter to the dead, in Papyrus Leiden I 371, a husband-sender addresses his dead wife recipient saying: I did not conceal anything from you during your lifetime. I did not let [you] suffer pain from anything that I did with you in the manner of a lord ( $b w p w=j d j t ~ s n[j=t] m r j r=j n b m-d j=t$ $m$ shr $n n b) .{ }^{10}$ The text describes Ankhiry's loyalty to his wife as he avoids the temptation of other women and he treats his wife gently in the manner of a lord, so that she did not suffer any psychological pain. ${ }^{11}$

\section{PAIN INFLICTION}

Solitude and loneliness are negative feelings, which can inflict pain. In the Middle Kingdom Story of the Shipwrecked Sailor, the attendant suffers painful experiences caused by his solitude, ${ }^{12}$ and most of the tale comprises dialogues between personages suffering from loss of society. This is attested in the Snake's Story, where the sailor says: How happy is he who relates what he has tasted (experienced) when something painful passes (snj ht $\mathrm{mr}$ ). So let me relate to you something similar that happened in this island..$^{13}$ In a similar way, Sinuhe experienced the pain of solitude when he was exiled to a foreign country. ${ }^{14}$

A lack of water generates a painful infliction, which is experienced by king Sety I and his expedition. In the Dedicatory Inscription of Sety I in his rock temple of Wadi Mia at El Kanais in the Eastern Desert, the king ordered that a well should be dug to provide water for his expeditions. On the north wall of the main hall, the text states that the king inspected the desert lands as far as the mountains to see the mines of the fine gold. After he searched for many miles, he said: How painful is a way that has no water (qsn.wy w3t jwtj

5 Sinuhe B 132-134; Allen 2015: 103-104; Nyord 2009: 93.

6 James Allen translates this word as 'mind' and not 'heart'; see: Allen 2015: 111.

7 Sinuhe B 161-162; Allen 2015: 110-111; Nyord 2009: 93.

8 The noun ' $m n w$ ' is a rare alternative form of ' $m n t$ '; see: Barns (Ed.) 1956: 3, A 4.

9 P. Ramesseum I; see: Barns (Ed.) 1956: I B ii 1; see also there: III A 7, B 3, IV A 3, C4.

10 P. Leiden I 371, rt. 17-vs. 19; see: Gardiner, Sethe 1928: 8-9, Pls VII-VIII; Troy 2015: 409, n. 1.

11 Troy 2015: 410.

12 This is stated in the words of the sailor as he says: Then I was put on an island by a wave of the sea. I spent three days alone, my mind is my only companion; see: Allen 2015: 18.

13 P. Hermitage, 1. 124-125; Allen 2015: 33.

14 Sinuhe B 161-162; Nyord 2009: 93. 
$n m w=s)$ ! What are travellers to do to relieve the parching of their throats ${ }^{15}$ The king here is influenced by the negative feeling of deficiency, describing the desert path as painful because it lacks water. In this context, pain is described in its emotional perception.

Speechlessness is a symptom of pain infliction. In the New Kingdom Lamentations of Khakheprre-soneb, he complains that he has no one in whom he can confide his woes, as those who know their cause wilfully shut their eyes to the truth and refuse to listen. Thus, he states that being speechless inflicts a painful feeling, saying: I am saddened in my heart, it is painful to conceal my inside over it (yet I keep quiet about it!) ${ }^{16}$ (whd ${ }^{17}$ sw hip $h t=j h r=f)$, it would be the bowing of another heart. ${ }^{18}$ The concealment of his inside in the text refers to his silence. In contrast, the repetition of a gossip causes pain. In Maxim 22 of the Teaching of the Vizier Ptahhotep, gossip is a dream causing pain, so one should cover over it (sswn rswt pw hbs.t. $(w) h r=s) .{ }^{19}$

Ignorance is another symptom of pain infliction. In the conclusion of the Teaching of the Vizier Ptahhotep, the latter says: As for the fool who does not hear, he will not be able to see anything. He sees knowledge as ignorance, what is useful as what is painful $(m 33=f r h m ~ h m$ 3ht $m$ mnt $){ }^{20}$

Crimes such as robbery can inflict a psychological pain. This is attested in a letter on the Middle Kingdom Papyrus UCL 32200, documenting a robbery in the residence and describing it, reading: As for the things you wrote about [concerning what] the reporter has done about the thief. Look, that is his responsibility. Look, what is being done in the Residence is more painful than anything ( $m$ t qsnt jrrt $m$ hnw $r$ ht $n b t){ }^{21}$

In the Report of Wenamun, which probably dates to the Twenty-first Dynasty, Tchekerbaal, the prince of Byblos wept after his secretary reported to him that Wenamun was fearful of arrest. Once the news was delivered the text states: The prince began to weep because of the words that were told to him, for they were painful $(m d(w) t \underline{j}-\underline{d} d=w$ $n=f j w=w m r){ }^{22}$

In a letter to the dead on the $\mathrm{Hu}$ bowl, dating to the First Intermediate Period, ${ }^{23}$ a mother who suffers pain writes to her husband Nefersefkhi, on behalf of her daughter, who is treated unjustly. She says: Execute your judgement on him who does what is painful (jr mr) for me, as I am justified towards any male and female dead who does this against my daughter. ${ }^{24}$ It is evident that the spirit of the dead husband can judge whoever harms his daughter painfully. The offender against whom the complaint is made is unknown. However, the offender controls the property of the dead Nefersefkhi to whom the letter is addressed.

\footnotetext{
15 Lichtheim 1980: 53.

16 Parkinson 1997a: 147.

17 For ' $w h d$ ', see: $W b$ I, 356, 2. For further information about this word, see: Kolta, Tessenow 2000: 38-52.

18 P. BM EA 5645, rt. 12-13; see: Gardiner 1909: 102, 104; Parkinson 1997b: 58; Quirke 2004: 174.

19 P. Prisse 11, 8 (1. 160); see: Parkinson 1997a: 258; Allen 2015: 198-199.

20 P. Prisse 17, 4-9 (11. 575-578); see: Allen 2015: 219-220.

21 P. UCL 32200, XV, 1, Letters; see: Griffith 1898: 72, Pl. 30, 11. 7-8; Collier, Quirke (Eds) 2002: 100-101.

22 P. Moscow 120, 2/67-2/68; Lichtheim 1976: 229; Ritner 2009: 91, 97.

23 This bowl is preserved in the Edwards Library, University College London; see: Gardiner, Sethe 1928: 5

${ }^{24}$ Gardiner, Sethe 1928: 5, Pls IV-IV A., 11. 4-6; Zandee 1977: 264.
} 


\section{PAIN HEALING}

In the Middle Kingdom story of the Debate between a Man and his $\mathrm{Ba}$, his soul inflicts misery, when it fails to suppress the negative feeling of pain. During the dialogue, the man admonishes his $b a$ for being foolish, since it is incapable of healing or repressing pain while living, saying: My soul is too foolish to suppress pain while living ( $b 3=j$ wh 3 . (w) $r$ sdh $3 h$ hr ( $n h$ ), one who prods me to death before I have come to it, who sweetens the West for $m e .^{25}$

Removing pain through one's heart can heal the unpleasant feelings. In the Lamentations of Khakheprre-soneb, he states: If only I had a heart with knowledge of suffering, then I could manage to alight on it, to weigh it down with words of misery, so that I might remove through it my pain $(d r=j n=f m n=j) .{ }^{26}$ The implication being that if his heart obeys him, his suffering would come to an end and the pain would be removed.

Humans can take part in the alleviation of pain as healers within a social context. Thus, pain is included within instructions for moral and ethical standards of behaviour in ancient Egypt. On the Twenty-fifth Dynasty block statue of Amenirdis, daughter of king Kashta from Hawara (Berlin Museum 8163), she acts as a pain healer stating: I have done what people love and gods praise, (as) one truly revered who had no fault, who gave bread to the hungry, clothes to the naked, removed pain (dr mnt), suppressed wrongdoing. ${ }^{27}$

\section{SOCIAL AETIOLOGY OF PAIN}

\section{PAIN FEELING}

In the Middle Kingdom Tale of the Eloquent Peasant, Khunanup expresses his feeling of pain through his weeping, ${ }^{28}$ with no intervention of any god to relieve his pains and misery. Consequently, he addresses the chief steward, saying: You do not show mercy, you do not feel pain (nj sf.n=k nj mn.n=k), you do not wipe out anything. You do not give me a return for this good speech that comes from the mouth of the Sun himself. ${ }^{29}$ The speech of the Eloquent Peasant here describes the injustice of the impious high steward, who is no longer a representative of the gods.

The Nineteenth Dynasty Lament of Ipuwer, preserved on Papyrus Leiden I 344, has many statements of social woe, chaos and destruction of the land. It is a dialogue between Ipuwer and the Lord of All dominated by laments of social woe. Ipuwer describes how the poor were in the place of the rich, poverty, famine and misery prevailed. He pictures the poverty of the Egyptians and the shortage of provisions and nourishment as a painful feeling. Thus, he says: There is no food [...] and today, how does it taste, today? No: the officials are starving and in pain (jw ms srw hqrw hr swn). ${ }^{30}$

\footnotetext{
${ }^{25}$ P. Berlin 3024, 1. 17-20; see: Allen 2015: 333.

${ }^{26}$ P. BM EA 5645, rt. 13-14; see: Gardiner 1909: 105; Quirke 2004: 174.

27 Gunn 1934: 137; Lichtheim 1980: 27.

28 Parkinson 1997a: 60; Allen 2015: 425.

29 P. Amherst 1; P. Berlin 3023, B1 347-350; Allen 2015: 314, 437.

30 P. Leiden I 344, 4, 11. 13-5, 1. 2; see: Quirke 2004: 143.
} 


\section{PAIN INFLICTION}

On the First Intermediate Period Naqada stela of the steward Seneni of Coptus (CG 20500), ${ }^{31}$ he refers to a long famine and deficiency of crops, saying: I measured out Upper Egyptian barley as sustenance for this whole town in the gateway of the Count and Chief Priest Djefi, in the painful years (rnpwt qsn $(w) t$ ) of distress. ${ }^{32}$

The feelings of pain and misery prevailed throughout Egypt during foreign invasions that caused many troubles and chaotic circumstances. This is attested in the Middle Kingdom Teaching for King Merikare; it reads: But now, these things are said about the barbarian: the vile Asiatic is the pain of the place where he is (js $3 \mathrm{mw}\{\underline{h} \mathrm{sj}\}$ qsn pw n bw ntj=f jm) - lacking in water, difficult with many trees, whose roads are painful (w3wt jrj qsn(w)) because of the mountains. He has never settled in any one place, lack of food making him wander away on foot! ${ }^{33}$ Further, in the Middle Kingdom Words of Neferty, the land of Egypt is in pain because of the invasions from the east. Therefore, all happiness has fled, and the land is laid low with pain ( $b w$ nfr $n b$ rwj pth $m t 3 \mathrm{~m}$ qsnt), by those feeding Syrians who go throughout the land. Enemies have arisen in the East! Asiatics have come down to Egypt. ${ }^{34}$ The text provides a description of the invasion comparing past pleasures with present dangers.

In the Victory Stela of Piankhi, the Asiatics received severe and painful defeat. This is attested within the text: It is the year for finalizing a conclusion, for placing fear of me in Lower Egypt, and for inflicting upon them a severe and painful defeat $(j r(t) n=s n$ sht $q(3) t$ qsnt $m$ ḥ(wj)). ${ }^{35}$

\section{PAIN HEALING}

In the Lament of Ipuwer, ${ }^{36}$ he describes the collapse of Egypt and speaks about civil war, foreign invasion and social disorder. He describes the perishability of grain, laments the lack of crops in the storeroom, and rebukes himself for not having spoken out saying: The grain is perished on every path; the one stripped of clothes is anointed with oil. Everyone says: there is nothing. The storeroom is bare, its guard stretched out on the ground, with plants that is from for my heart. I am entirely estranged. If only I had made a sound at that moment, so that he would save me from my pain inflicted there ( $h \mathrm{hm}=f \mathrm{wj}$ $\left.m^{-}{ }^{C} w h d t^{37}=j j r . t w j m=s t\right) .{ }^{38}$ It is likely that Ipuwer calls out the Lord of All to heal and save him from his pain.

31 Fischer 1964: 67-68, P1. 18.

32 Lichtheim 1973: 89-90.

33 Merikare E 91-92; see: Parkinson 1997a: 223, 34 (P 91); Quack 1992: 54-55.

34 P. Hermitage 1116B, 31-33; see: Helck 1970: 27; Parkinson 1997a: 136, 7 (P 31-33).

35 Ritner 2009: 471, 481, 1. 31.

${ }^{36}$ For the identity of Ipuwer, see: Gardiner 1909: 7. For a new edition of this papyrus with numerous corrections, see: Enmarch 2005; 2008.

${ }^{37}$ For ' $w h d w$ ', 'physical pain', see: $W b$ I, 356, 14; Faulkner 1972a: 68

38 P. Leiden I 344, 6, 11. 2-5; see: Quirke 2004: 144. 


\section{Religious Aetiology OF PAIN}

\section{PAIN FEELING}

Deities are susceptible to various feelings of pain infliction. The pain suffered by Horus, as a result of his wounds, is demonstrated within the Contendings of Horus and Seth. Thus, in a magical incantation of Papyrus Leiden I 345, Horus cries to his mother Isis seeking her help against any pain $(m n(w))$ generated by his wounds. ${ }^{39}$ In chapter 17 in the Book of the Dead, the verb ' $m n$ ' is used to designate the pain in the head of J3hsy. ${ }^{40}$ The latter says: I am J3hsy at his going forth; (I) have put my twin plumes on my head. What is that? As for 'J3hsy', he is Horus who saved his Father. As for 'his going forth', they are his Children. As for 'his twin plumes on his head', Isis and Nephthys went and put themselves on his head, being present as hawks while his head was paining him (mn $t p=f){ }^{41}$

Gods, like humans, are susceptible to the painful feeling of scorpion stings. In the Ramesside Incantation of Isis and the Name of $R e,{ }^{42}$ the latter suffers severe pain due to being stung by a scorpion. He had a secret name, which he concealed from the other gods, and he was so old and feeble that he drooled at the mouth. Isis tricked him by kneading his spittle into a scorpion, which stung him painfully. The great god Re cried for his followers saying: Something painful (ht mrt) has stung (dm) me, but my heart knows it not. My eyes did not see it. My hand has not made it and $<I>$ do not recognise it among anything I have made. I have never tasted a suffering like it ( $n n d p . n=j m n r-m j t t=s$ ); there is no greater pain than this ( $n$ n $m r r=s$ ). ${ }^{43}$

The heart of the god can be inflicted with pain that expresses compassion for the Sacred Eye. This is attested in spell 768 of the Coffin Texts, as the deceased addresses the god saying: O you whose heart pains for the Sacred Eye ( $j \mathrm{mr} j \mathrm{j} n \mathrm{n} \mathbf{d} 3 \mathrm{t}$ ), if $N$ be aware do not be unaware of him. ${ }^{44}$ However, pain in this case has a metaphoric perception of compassion rather than its agonising effect.

In spell 37 of the Coffin Texts, Osiris suffers a sore pain from the wounds, which were inflicted by the allies of Seth. In this spell, the deceased addresses Osiris saying: $O$ Osiris, see that foe who is among men and who is in the necropolis has come, having joined with Seth. He has disturbed your weariness, he has said that your wounds are hidden, he has said: Sore be the pains of your suffering which are on you ( $m r$ js $m r t m n(w)=k$ $j r=k){ }^{45}$

\footnotetext{
39 P. Leiden I 345, vs. XXII, 8-9; Massart 1954: 44, 112.

$40 J$ J h sy is a name of Horus who saved his father; see: Allen 1974: 28. J3hsy is also a name of Min; see: Hornung 1979: 62 .

41 Allen 1974: 28.

42 P. BM 10691; Gardiner (Ed.) 1935: 116-119, Pls 64-65A.

43 Borghouts 1978: 52; Möller 1961: 30.

${ }^{44}$ See: CT VI, 399m-n [768]; Faulkner 1977: 297; Carrier 2004b: 1720-1721.

45 CT I, 155b-h [37]; Faulkner 1973: 28; Carrier 2004a: 72-73; Willems (Ed.) 2001: 310-311.
} 


\section{PAIN INFLICTION}

In the Pyramid Texts, the deceased has to pass through dangerous places ${ }^{46}$ in the afterlife, such as 'pr B3-pf', 'the house of Bapef' ${ }^{\prime 47}$ and ' $\check{s} w r$ ', 'the great lake'. In utterance $666 \mathrm{~B}$ of the Pyramid Texts, the house of Bapef is painful, ${ }^{48}$ since Bapef is a malevolent deity, who inflicts pain. This text cautions queen Neith about this terrible place, reading: $O$ Neith ... Beware of those people of the House of Bapef (s3 tn rmt jptf $n(y) t \mathrm{pr} B 3-p f)$ who are terrible and hostile in this their name of 'Female Opponents'. Do not let them lay hold of your hand in the House of Bapef; it is dangerous, it is painful, it is nasty(?), it is foul-smelling ( $p r$ B $3-p f s w(=w) s w \operatorname{mr}(=w) s w n h(=w) s w j 3 b(=w) s w) .{ }^{49}$

Another malevolent god is Seth, who is known to inflict pain on Osiris. ${ }^{50}$ In the Contendings of Horus and Seth, spell 157 of the Coffin Texts, ${ }^{51}$ and chapter 112 in the Book of the Dead, ${ }^{52}$ Seth, in the form of a black pig, causes pain to the eye of Horus.

Scorpion goddesses, as inflictors of pain, are known for their malefic attacks, delivering pain through their stings. ${ }^{53}$ In chapter 39 in the Book of the Dead,${ }^{54}$ the stings of the scorpion goddess Hededet $(H d d t)$ are painful to Apophis, reading: Apep the enemy of Re has fallen down, and what you have experienced is greater than the experience which is in the heart of the Scorpion-goddess, great is what she has done against you with the everlasting pains ( $\left.w r^{55} j r(j) . n=s r=k m r . t j\right)$ which are hers. This shows that deities can harm other malevolent gods, inflicting pain in order to defend a third deity, the sun god in this case. ${ }^{56}$

Satis, as a pain inflictor, defends the deceased against his enemies with her painful arrows. This is attested in spell 313 of the Coffin Texts, as it reads: Those who shall come

${ }^{46}$ The slaughter place of the god is another painful place, which the deceased has to pass in the Netherworld. For the slaughterhouse of Khemennu, see: $C T$ I, 232a [50]; Faulkner 1973: 48. For the slaughtering-place of Soped, see: $B D 130$ b, § S 2; Allen 1974: 180.

${ }^{47}$ Bapef is an obscure malevolent deity, who is associated with pain or spiritual anguish, which inflict the deceased king or any deceased. His name means 'that $b a$ '. For further information about this deity, his priestesses and cult, see: Gillam 1995: 213; Ziegler 2008: 168; Verner, Callender, Strouhal 2002: 148; Bryan 1991: 94; $L G G$ II: 680. Bapef appears on the upper register of the Third Hour of the Imy- $d w 3 t$ in mummiform with bull's horns; see: Hornung, Abt 2007: 85.

${ }^{48}$ Although the houses of specific deities are painful places, like the house of Bapef, deities can dwell in the house of pain. In the Mythological Manual Florence, 'Tefnut in the House of Pain' is assimilated to Nehbetanet; see: PSI inv. I 72 x+5, 7-14; Osing, Rosati 1998: 171-172; Lieven 2015: 192.

${ }_{49}$ PT 666 B, §§ 1930c-1931c; Carrier 2010b: 2574; Faulkner 1969: 279.

${ }^{50} C T$ III, 3d-4c [164]; 322c [239]. The word ' $s q b b$ ' is commonly used to designate the alleviation of the pain inflicted on Osiris by Seth. In $P T 324, \S 521 \mathrm{a}-\mathrm{c}$, the king comes to Horus as a healer, who heals ' $s q b b(w)$ ' the god with magic; see: Carrier 2010a: 860-861; Faulkner 1969: 103.

${ }^{51}$ CT II, 341a [157]; see: Carrier 2004a: 386.

${ }_{52}$ BD 112, 6-7; Faulkner 1985: 108-109; see also: Allen 1974: 91.

${ }^{53}$ The sting of scorpions inflicts severe pain. For examples of anti-scorpion spells, see: Borghouts 1970: 13. In a New Kingdom incantation against snakebites the symptom is a burning pain; see: P. BM EA 9997; Leitz 1999: 5 .

${ }^{54}$ Borghouts 2007: 14; Allen 1974: 46; cf. Goyon 1978: 448.

${ }_{55}$ Other versions of this chapter have 'qsn', 'painful' instead of ' $w r$ ', 'great'. Thus, this part reads: Painful is what she has done against you; see: Borghouts 2007: 14, n. 62.

${ }^{56}$ Faulkner 1985: 60; Carrier 2009: 166. 
against you from the South shall be driven off by Satis, Lady of Elephantine, who will shoot at them with her arrows $(s \underline{t} t(w)=s r-s[n] m \check{s} s r w=s p w)$, which are painful and sharp (mrw spdw) [against(?)] them. ${ }^{57}$

Maat who personifies truth and justice, can also cause pain. This unusual perception of divine pain infliction is clearly conveyed emotionally in the Tale of the Eloquent Peasant. The peasant appealed to the High Steward a sixth time saying about Maat as a personification of truth and justice: See for yourself the divider a grasper, the pacifier a distressmaker, the evener a pain-maker (stwt $m$ jr $3 h w$ ). ${ }^{58}$

Anubis, and Horus Mekhentirty can inflict pain, although they are typically known as benevolent gods. In chapter 17 in the Book of the Dead,,$^{59}$ they are described as the ones who deal wounds, the slayers whose fingers are sharp, and the painful ones ( $m r w)$. Similarly, Osiris, ${ }^{60}$ the most benevolent of all deities, inflicts pain through his slayers, who use their fingers ${ }^{61}$ to inflict painful injuries. These injuries are inflicted by their sharp nails (' $n w t) .{ }^{62}$ This is attested in spell 335 of the Coffin Texts as the deceased addresses Re saying: ( $O R e$ ), save me from those who inflict wounds, the slayers of Osiris whose fingers are painful (mrw $\underline{d} b^{\complement} w n(y) w W$ sjr). As for the slayers who belong to Osiris, they are this company which takes action against the foes of Osiris. ${ }^{63}$ Painful fingers which inflict wounds are also mentioned in spell 335 of the Coffin Texts; it reads: $O$ Lord of the Enneads, save me from those who inflict wounds, whose fingers are painful $(j r(y) w$ st $3 w$ $\left.m r w \underline{d} b^{\ulcorner} w\right){ }^{64}$

The concept of pain infliction against the enemies of a specific god is included on the middle register of the Tenth Hour in the Imy- $d w 3 t$, where there are representations of twelve gods, one for every hour, which personify the bodyguards of the sun god, protecting him against all his enemies. One of the four middle gods, who carry spears ${ }^{65}$ is named

${ }^{57}$ CT IV, 891-m [313]; Faulkner 1972b: 92; 1973: 234; see also: Carrier 2004a: 730-731. Neith, as a protective goddess, shoots arrows like Satis. On the east wall of Room L of Hibis temple, there is a text stating that Neith shoots her arrows into the enemies of her son, who is likely Horus; see: Cruz-Uribe 1988: 112. For Neith as a goddess of popular cult, who shoots a demon with her arrows, see: Daressy 1910: 177-179, Figs 1-2; El-Sayed 1982: 482-483, Pl. XI (Doc. 679 a).

${ }_{58}$ P. Amherst 1; P. Berlin 3023, B1 278-281; Allen 2015: 295-296, 434. Deities usually show their mercy to the individuals. The god shows ultimate mercy for Sinuhe, resulting in his success; see: Griffiths 1988: 43-94.

${ }^{59}$ Faulkner 1985: 48.

${ }^{60}$ For the aggressive and violent nature of Osiris as a malevolent god, see: Kákosy 1977: 285-288; Žabkar 1988: 32-33.

${ }^{61}$ The aggressive usage of fingers is attested when the deceased uses them to tear something apart in an act which is designated ' $3 \check{s} d$ '. This is attested in the text of CT IV, 92g [313], which reads: I have bruised(?) them

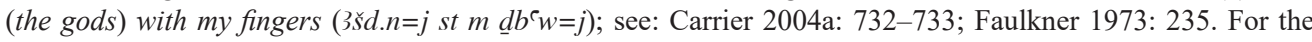
assimilation of the deceased's fingers to the arrows of Sekhmet (' $n w t=j r=f m$ sšrw Shmt), see: CT II, 237b [149]; Carrier 2004a: 358-359; Faulkner 1973: 127. Their epithet 'painful of fingers' indicates that the slayers of Osiris can inflict painful injuries to the dead; see: Zandee 1977: 152.

${ }^{62}$ Nyord 2009: 270-275.

${ }^{63}$ CT IV, 303a-304b [335]; Faulkner 1973: 265; Carrier 2004a: 826-827; see also: Meeks 1996: 144, n. 16.

${ }^{64}$ CT IV, 330g-h [336]; Carrier 2004a: 838-841; Faulkner 1973: 271.

65 The spear is used as a divine weapon; for the spear of Horus, see: Alliot 1949: 323-325. 
' $n k n w$ ', ${ }^{66}$ 'who causes pain' ${ }^{67}$ Further, on the lower register of the Ninth Hour, there are representations of twelve cobras, which spit fire with flames from their mouth, for Osiris, the Foremost of the Netherworld. The first cobra is called ' $m r t n s(r)$ ', 'She with painful ${ }^{68}$ flame' ${ }^{69}$

Benevolent gods can inflict pain on humans as a punishment for their transgressions and evils. This is attested in a letter of the Ramesside Papyrus BM 10429, with the sender Neferhor asking an anonymous woman to go and tell her people to present offerings probably to Amun-Re. They interceded on his behalf to the god, since he had sinned; and therefore, a pain in his upper arm $(r m n=j m p 3 y m r)$ is caused by a divine infliction for his transgression as he says: Truly, I was wrong. ${ }^{70}$

A portal in the House ${ }^{71}$ of Osiris, in the Field of Rushes is a place of pain. The deceased addresses this portal saying: I know your name, and I know the name of the god who guards you. 'Hot of flames, destructive of heat, sharp of blaze, swift of hand, who kills without warning, whom none pass by for fear of her pain' is your name (jwty sw3 hr=s $n$ snd $n(y) j h=s \quad r n=t){ }^{72}$

The funerary texts usually describe the West as a beautiful region. ${ }^{73}$ However, in spell 312 of the Coffin Texts ${ }^{74}$ and chapter 78 in the Book of the Dead, the deceased says: I go to the place where dwells He who sleeps, being helpless, who is in the Field of Eternity, who was conducted to the painful western darkness $(\operatorname{sšm}(w) . n=f r k k w \text { mrw jmntyw) })^{75}$ (even) Osiris. ${ }^{76}$ This painful western darkness probably refers to the realm of the dead on the West Bank.

${ }^{66} \mathrm{~Wb}$ II, 347, 4. For the verb ' $n k n$ ', see: $W b$ II, 346, 8. For ' $n k n$ ' as the name of Osiris, see: $W b$ II, $347,3$.

${ }^{67}$ Hornung, Abt 2007: 313. Some of the other deities who accompany ' $n k n w$ ' have names indicating pain infliction, since their weapons cause pain. They are called archer, shooter and arrow-shooter; see: Hornung, Abt 2007: 313 .

${ }^{68}$ In spell 316 of the Coffin Texts, the deceased says about himself: I am strong and painful of flame (jnk nht mrt ns(r)); see: CT IV, 106c-e [316]; Faulkner 1973: 239; Carrier 2004a: 746-747.

${ }^{69}$ Hornung, Abt 2007: 290; Roberts 2000: 150. The name of a female fire-demon, which burns the enemies of Osiris, is the fiery serpent; see: CT IV, 260c [335]; Faulkner 1973: 64; Piankoff 1942: 264. For ' $m r t$ nsrt', see: $\mathrm{Wb}$ II, 95, 11, 16-17.

${ }^{70}$ P. BM 10429, rt. 6, vs. 1-4; Janssen 1991: 41-42, Pls 25-26. For pain in the arm in medical papyri, see: P. Ebers 191 (37, 10-17); Ghalioungui 1987: 57.

71 The gods have houses, which seem to be different from their temples, where they used to live. The reigning gods enlarge and embellish their residences at pains; see: Meeks 1996: 85. The text of the stone of Shabako states that Osiris was buried in the House of Sokar; see: Lichtheim 1973: 53. For the houses of Ruti, Osiris, Isis, and Dunanwy, see: Willems 1996: 268-269; CT IV, 81f-i [312]; Faulkner 1973: 231.

72 Allen 1974: 145; Faulkner 1985: 136; Carrier 2009: 592.

73 The text of CT I, 241g [53] reads: The Osiris $N$ has appeared in peace in the beautiful West (Wsjr $N$ pn h'y $m$ htp n jmnt nfrt); Faulkner 1973: 52; Carrier 2004a: 128; Willems 1996: 197. The deceased travels in peace to the beautiful West in CT I, 234d-e; see: Faulkner 1973: 50. For gatekeepers sitting close to the beautiful West, see: Chassinat 1909: 56.

${ }^{74}$ CT IV, 81d-e [312]; Faulkner 1973: 231; Carrier 2004a: 722-723. The Egyptians describe the Netherworld as a place of loneliness and darkness; see: Assmann 2005: 164.

75 Nyord 2009: 219. For ' $k k w$ mrw jmntyw', the 'painful darkness of the westerners', see: Hornung 1990: 74. For Osiris as 'hnty-kkw', 'foremost of darkness', see: Piankoff, Rambova 1957: P1. 13 (first scene).

76 Faulkner, Goelet 1998: 70; Buck 1949: 95. 
In chapter 148 in the Book of the Dead, the deceased invokes the ancestor deities to evade a trap with painful knives, where he would be tortured. ${ }^{77}$ The text reads: $O$ fathers of the gods and mothers of the gods who are over sky and earth and who are in the realm of the dead, save me from all kinds of harm and injury, from the trap with painful knives $(\mathrm{mr} d \mathrm{mwt})^{78}$ and from all things bad and harmful. ${ }^{79}$ The Lake of Fire is also a place of pain in the Netherworld. On the lower register of the Fifth Hour, this lake ${ }^{80}$ is shown in the form of waves, occasionally painted red indicating its fiery nature resulting in the painful punishment for the sinners. ${ }^{81}$

In contrast to their malign role, demons can ward off pain inflicted by the enemies of Osiris. This is attested in the Book of the Gates, where Horus orders four demons, guarding four traps; ${ }^{82}$ it reads: Seize for you the enemies of my father, whom you have dragged away to your traps on account of this pain they have inflicted ( $n \underline{d} r w n=t n h f t y w j t=j$ hnp $(w) n=t n$ $r$ ḩ3dw=tn $h r$ nn mrw jrywn $=s n) .{ }^{83}$

\section{PAIN HEALING}

Deities may seek a relief of pain, but they have their own reliefs and remedies. The living and dead appeal to various gods with the aim to alleviate their pain. In spell 32 of the Coffin Texts, the deceased, who is portrayed as a young Horus-like god, is addressed reading: May you greet him (i.e. Osiris), may you calm his pain, O Osiris in Djedu (sndm=k $j h=f$ $j$ Wsjr $m \underline{D} d w$ ), in his dignity of Bull of the West. $N$ has come to where Your Majesty is, he will dispel your pain $(d r(w)=f j h=k)$, he will make your foes tremble. ${ }^{84}$

The two words ' $j h$ ' and ' $m r$ ' 85 can be used together to mean a 'sore pain' of a god. This is attested in chapter 130 in the Book of the Dead, which reads: Horus flames up around his eye, and his two Enneads are about his throne; if they remove the sore pain which he suffers ( $d r=s n$ jh $\mathrm{mr} m n=f)$, then will I remove the pain $(d r j h)$, that I may be made comfortable thereby. ${ }^{86}$

Deities, like humans, feel pain in their hearts. They may appeal to each other with the aim of removing that negative feeling. In the Ptolemaic Lamentations of Isis and Nephthys, in Papyrus Berlin 3008, Nephthys addresses Osiris, saying: Turn around on your bier! See the women, speak to us! King our lord; you may drive out all the pain, which is in

77 In the Book of the Dead, flint knives are used against the enemies of the gods; see: BD 172, $\S \mathrm{S} 5$; Allen 1974: 180. For further information about the usage of knives in torturing Apophis and the companions of Seth, see: Ritner 1993: 163, n. 758.

78 Carrier 2009: 613.

79 Zandee 1977: 255; Faulkner 1985: 137.

${ }^{80}$ For further information about the Lake of Fire, see: Abbas 2010.

81 Hornung, Abt 2007: 171.

82 For traps of the deceased in the afterlife, see: $B D$ 153; Faulkner, Goelet 1998: 123. For fish-traps and bird-traps for the dead, see: Zandee 1977: 168-169, 230.

${ }^{83}$ It is written on the lower register of the $22^{\text {nd }}$ scene in the Book of the Gates; see: Hornung, Abt 2014: 137.

${ }^{84}$ CT I, 100c-104b [32]; Faulkner 1973: 21; Carrier 2004a: 52-53; Jüergens 1995: 268-269.

${ }^{85}$ For the different meanings of the word ' $m r$ ' and its Egyptian-Semitic root, see: Ward 1980: 357-360.

86 Faulkner, Goelet 1998: 117; Faulkner 1985: 119. 
our hearts! $\left(d r=k 3 h w^{87} n b\right.$ nty $\left.m j b w=n\right)$ Your court of gods and men beholds you, show them your face, King our lord! ${ }^{88}$ This text clearly states that Osiris, as a benevolent god, removes and alleviates pain and misery of the heart.

It is self-evident that the deities hear the petitions of those who suffer pain and intervene to alleviate it. This is attested in chapter Pleyte 174 in the Book of the Dead, ${ }^{89}$ as Anubis addresses the sole god saying: You who know the tongue of one who suffers pain in his

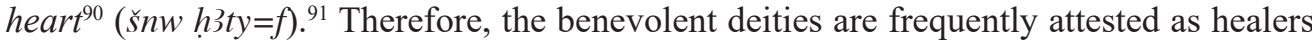
who relieve sufferings and pains of people. ${ }^{92}$ Amun-Re is petitioned in an inscription on the Twenty-fifth stelophorous statue of Mentuemhat at Cairo Museum, ${ }^{93}$ where the owner addresses Amun saying: Hail to you, Amun, Maker of Mankind, god who created all beings! ... I bow down to your name, may it be my physician, may it remove my body's illness, may it drive pain away (from me) $\left(d r=f\right.$ mnt $n w h^{\complement} w=j s h r{ }^{94}=f n$ whd $) .{ }^{95}$

Foreign deities are also invoked to alleviate pain. Reshep, as a god of healing, ${ }^{96}$ was invoked and petitioned in a spell to overpower inimical influences like the demon Akhu $\left({ }^{\circ} h w\right)$ who was believed to cause abdominal pain. ${ }^{97}$ Further, in Amarna letter EA 23, king Tushratta of Mittani states that he was sending along a statue of the healing goddess Ishtar (Šauška) of Nineveh. It is argued that the goddess's statue was probably sent to cure painful abscesses in the teeth of Amenhotep III. ${ }^{98}$

In a different context, other deities are invoked to alleviate the pain of a difficult childbirth. In the tale of the Birth of the Royal Children in Papyrus Westcar, the three children were delivered by Ruddjedet, whose labour was painful. Consequently, Re asks Isis, Nephthys, Meskhenet, Heket and Khnum to deliver Ruddjedet of the children in her womb and to relieve her labour pains. When they reach the house of Rawoser, Re addresses the goddesses saying: My ladies, now is the moment the woman who is in her pain (hnwt=j mtn st pw ntt hr $m n=s) ;{ }^{99}$ her birthing is difficult. ${ }^{100}$ Isis, as a goddess of motherhood, particularly reduces the pain of delivery. ${ }^{101}$ This is attested in a text surmounting the pylon, which precedes the chapel of Amenirdis, the divine adoratrice of Amun, at Madinet Habu temple

${ }^{87}$ For '3hw', 'pain', see: $W b$ I, 12, 4.

${ }^{88}$ P. Berlin 3008, 3, 4-3, 7; see: Faulkner 1934: 339, P1. 2; Lichtheim 1980: 118.

${ }^{89}$ It is a 'spell for causing the Presider over the West to go forth to the Netherworld'; see: Allen 1974: 223.

90 For pain in the heart, see: Borghouts 1970: 10; see also: Wilson 1997: 12.

91 Allen 1974: 223.

92 For the role of deities in easing and relieving humans' sufferings and crises, see: Guerry 2007: 109-123.

${ }_{93}$ The statue carries number CG 42237. It was found in the great temple of Amun-Re at Karnak; see: Leclant 1961: P1. VI.

${ }^{94}$ For the verb 'shrj', 'drive away', see: Faulkner 1972a: 238.

95 Lichtheim 1980: 30.

96 Cornelius 1994: 259.

97 Leiden Magical Papyri I 343 + I 345 (rt. XI, 13); Münnich 2013: 91; Hart 2005: 137.

98 Hayes 1973: 346; Redford 1984: 52, 54. This argument is rejected by William Moran who suggests that the goddess was sent to Egypt to bless the wedding of Amenhotep III and Tadukhepa; see: Moran 1992: 62, n. 2.

99 Quirke 2004: 86.

100 P. Westcar, 9, 21-25 = P. Berlin 3033; Lichtheim 1973: 220; Mathieu 1999: 11.

101 The pain of childbirth ( $m r m s w$ ), is an ailment mentioned in Edwards 1960: rt. 116. 
of Ramesses III; it reads: She (Isis) makes married women bear without pain ( $\mathrm{nn}$ mr), and without damage ( $n n$ h $\underline{d}$ ) ${ }^{102}$ In the Oracular Amuletic Decree (Papyrus Turin 1984), Montu, Khonsu and the great gods of heaven and earth said: We shall keep her (Buiruharkhons whose mother is Djedkhons) ${ }^{103}$ safe from any (kind of) death and any (kind of) pain in giving birth (jw $n \check{s} d j=s$ tr $m(w) t n b r m r n b m s w){ }^{104}$

The deceased himself may take part in the alleviation of the gods' pain. Thus, he states that he has cured the great god (Re or Osiris?) from the pain in his head, shoulder and leg, so the headache is not his only distress. This may as well concern a wound and not only an infliction. ${ }^{105}$ This is attested in chapter 102 in the Book of the Dead ${ }^{106}$ which reads: I myself have come that I might save this god from those who would do him evil, namely the pain allotted to thigh, arm, and leg $\left(j j n=j \underline{d} s=j n h m(w)=j n t r\right.$ pwy $m-{ }^{\ulcorner} n w w$ $n(y w)$ jrww mn=f mr jpn jw`w q $\left.q^{\ulcorner} w^{\top} r t p w\right)$. I have come that I may spit on the thigh, tie up the arm, and raise the leg. ${ }^{107}$

\section{PhySiCAL AETIOLOGY OF PAIN}

\section{PAIN FEELING}

The word ' $m n$ ' is used as a verb that means, 'to be in pain'. ${ }^{108}$ It occurs frequently in the medical texts of Papyrus Kahun ${ }^{109}$ as a noun that means physical pains in the neck, teeth, jaws, abdomen, eyes' sockets, feet, legs, vulva, shanks and all the limbs of the body. Its feminine derivative is the word ' $m n t$ ', which is used as a verb, ${ }^{110}$ and a noun. ${ }^{11}$

Another word for feeling pain is the noun ' $t j 3$ ', 'acute pain'. ${ }^{112}$ It occurs twice in its plural form in Papyrus Kahun to mean the pains of the womb $(t j 3 w p w m j d t) .{ }^{113}$ It also occurs in its singular ' $t j 3$ ' and plural ' $t j 3 w$ ' forms to mean 'acute pain of a woman in labour'. ${ }^{114}$

${ }^{102}$ Daressy 1898: 74; Borghouts 1970: 152, n. 382.

${ }^{103}$ For further information about this lady, see: Edwards 1960: 10, n. 14.

${ }^{104}$ P. Turin 1984 = OAD T. 2, rt. 116; see: Edwards 1960: 67, Pls 24-24A; Borghouts 1970: 152, n. 382.

${ }^{105}$ Borghouts 1970: 11.

${ }^{106} B D, 102,8$ = Naville II, 139; see: Faulkner 1985: 100; Allen 1974: 84. A similar text is given in spell 164 of the Coffin Text; see: CT III, 3d-4c [164]; Faulkner 1973: 142; Carrier 2004a: 410-411.

107 Faulkner 1985: 100; Carrier 2009: 366.

${ }^{108} \mathrm{~Wb}$ II, 67, 8; Allen 2015: 219, 1. 578, 295, 1. 280.

109 P. Kahun VI, 1, Medical Texts, pages 1-2, prescriptions nos 1, 3, 5-9, 12; see: Griffith 1898: 6-9, Pl. 5, 11. 1, 9, 15, 19-21, 23, 25, 27, 36, 51. Prescriptions numbers one and eight are for a woman who has pain (mn) in the neck; number three for a woman who has pain ( $m n$ ) in the natibus suis; number five for teeth, jaws(?) and abdomen; number six for eye sockets; number seven for feet(?) and legs; number nine for vulva, and all limbs; number twelve for shanks; number sixteen for vulva, and all her limbs and the sockets of her eyes.

${ }^{110} \mathrm{~Wb}$ II, 67, 6-18. The word is used as a verb in prescription number thirteen of the medical texts in Papyrus Kahun; see: Griffith 1898: 8, P1. 5, 1. 43.

111 Wb II, 67, 19; Faulkner 1972a: 107.

${ }_{112} \mathrm{~Wb}$ V, 241, 4-5; Faulkner 1972a: 294. It is also used in Late Egyptian as a noun by the meaning of clamour, and as a verb by the meaning of cry out; see: Lesko, Lesko (Eds) 2004: 200.

${ }_{113}$ P. Kahun VI, 1, Medical Texts, page 3, prescriptions nos 5, 24; see: Griffith 1898: 9, Pls 5, 1. 16, 6, 1. 8; Faulkner 1972a: 294.

${ }_{114}$ P. Kahun VI, 1, Medical Texts, page 3, prescriptions no. 33; see: Griffith 1898: 11, Pl. 6, 11. 25-26. 
Further, it gives the meaning of the physical pain of a wound ' $t j 3$ hr wbnw' in Papyrus Edwin Smith. ${ }^{115}$ The word 'šnj' is used as a verb by the meaning of 'to feel pain', ${ }^{116}$ and 'to suffer'. ${ }^{117}$ It is also used to mean 'pain of childbirth'. ${ }^{118}$ In Papyrus Edwin Smith, the adjective ' $q s n$ ' 119 is used to express that it is painful for a man who has a gaping wound in his head to open his mouth (jw qsn rf wn $r=f$ ). ${ }^{120}$ The same word is also used twice to express that it is painful for a man who has a smash in his nostril or his cheek to open his mouth (jw qsn wn=f $r=f$ ). ${ }^{121}$ In the same papyrus, a man, whose cord of his mandible is contracted, cannot open his mouth because of his pain ( $\left.n n d m . n n=f w n \quad r=f m-{ }^{c} j h=f\right){ }^{122}$ The word ' $q s n$ ' is also used by the meaning of painful in other cases of Papyrus Edwin Smith. ${ }^{123}$ In a royal decree of Thutmose III related to public health, in Papyrus Berlin 3049, the sentence 'snfr [mn] $h^{`} w$ ' means 'to heal the one who [suffers] physically'. ${ }^{124}$ Thus, the word ' $m n$ ' here designates physical pain.

An incantation in Papyrus Berlin 3027 is entitled 'Incantation of a red woman ( $h m t$ dšrt) who has had multiple births(?)'. ${ }^{125}$ It describes the difficult labour of a woman enduring multiple births. The adjective ' $d \check{s} r t$ ' here conveys a sense of pain that needs to be healed through magical words and actions. ${ }^{26}$

In an obscure stanza from the Lament of Ipuwer, the noun 'mnt' describes the pain of his body. He urges the Lord of All to remember the pious man who was cured (lit. immersed) after suffering pain in his body saying: Remember the immersing [...] suffering for the pain of his body (sh3w thb [...] whdyw $r$ mnt $\left.=f h^{\ulcorner} w=f\right) .{ }^{127}$

\section{PAIN INFLICTION}

The Egyptian medical papyri provide accounts of pain in various human organs. Magicoreligious spells are recited to alleviate pain resulting from various diseases. ${ }^{128}$ Thus, the incantations of magical texts ${ }^{129}$ are recited to cure various pains. ${ }^{130}$ The expectation of being cured or relieved of pain caused by divine infliction would be enhanced through amulets

\footnotetext{
115 P. Edwin Smith III, 9; Breasted 1991: 181; Resche 2016: 104, n. 302.

116 Wb IV, 494, 15 (Schmerz empfinden); see also: Deines, Westendorf 1961: 856.

117 Borghouts 1970: 158, n. 382; Faulkner 1972a: 268.

118 Borghouts 1970: 158, n. 382.

119 For the word ' $q s n$ ' in medical texts, see: Deines, Westendorf 1962: 892.

120 P. Edwin Smith III, 3; Resche 2016: 103.

121 P. Edwin Smith VI, 5-6; VII, 3-4; Resche 2016: 103, 125.

122 P. Edwin Smith III, 17-18; Resche 2016: 107.

123 P. Edwin Smith VII, 16; VIII, 7-8; X, 9-10; XVI, 19-20; XVII, 17-18 ('qsn', ‘pain'); Resche 2016: 128,

124 P. Berlin 3049, vs. XVIII, 6; see: Vernus 1979: 176, 180-181, n. (h).

125 P. Berlin 3027, Spell V (vs. VI 1-7); Yamazaki (Ed.) 2003: 52-53, P1. 16.

${ }^{126}$ For the symbolism of the red colour, see: Brunner-Traut 1977: 124.

127 P. Leiden I 344, 10, 1. 12; see: Parkinson 1997a: 183, 196, n. 84; Quirke 2004: 147.

${ }^{128}$ For the exorcism of demonical pains through the recitation of a magical incantation, see: P. BM EA 10059, VI, 3-5; Leitz 1999: 61.

129 Magical incantations were also recited to alleviate the pain of menstruation; see: Stevens 2006: 299.

130 Pains of blister in the eyes are healed in the incantation 58 of London Medical Papyrus, P. BM EA 10059, XIII, 8-9; see: Leitz 1999: 79.
} 131,171 . 
and incantations and would have had a positive effect on the patient. ${ }^{131}$ In a conjuration spell for a nasal catarrh ( $r \check{s})$, the seven holes in the head suffer pain, stating: Break out catarrh, son of a catarrh that beaks the bones, that smashes the skull, that plays havoc in the brain and causes the seven holes in the head to suffer pain, (even they) the followers of Re who give praise to Thoth ${ }^{132}$ A subsequent part of the same spell reads: No offerings will be brought in Abydos until the influence ${ }^{133}$ of a god, the influence of a goddess, the influence of a male pain-substance (whd), the influence of a female pain-substance (whdt), the influence of a male dead, the influence of a female dead, ${ }^{134}$ and so on, the influence of anything bad that is in this body of mine, in this flesh of mine, in these limbs of mine, is removed! $!^{135}$ This incantation obviously differs from medical papyri regarding the treatment of pain. It involves major gods as if they are responsible for the pain infliction to the extent that they are threatened.

In the Teaching of the Vizier Ptahhotep, the city-overseer and vizier of king Djedkare Isesi, Ptahhotep addresses the king saying: The mouth has grown quiet, without being able to speak, the mind is closed, without being able to remember yesterday, the bone ${ }^{136}$ is in pain at length ( $q$ s mn(w) $n=f n 3 w w)$. Goodness has become badness. ${ }^{137}$ Ptahhotep describes how ageing has negatively affected his sight, memory and bones.

In the Middle Kingdom Tale of the Eloquent Peasant, he was weeping very greatly because of the pain ( $\mathrm{mr}$ ) of what was done to him (wn.jn shtj pn hr rmyt $3 \mathrm{w}$ wrt $n \mathrm{mr}$ $n$ jryt $r=f) .{ }^{138}$ Nemtinakht, the liegeman of the High Steward Rensi son of Meru, beats the limbs of the peasant using a stick of fresh tamarisk after stealing the peasant's asses and bringing them to his estate. ${ }^{139}$

131 Nunn 1996: 96-112.

132 Borghouts 1978: 34. Break out is used in magical texts against scorpions; see: P. Chester Beatty VII, rt. 7,5.7-7; Gardiner (Ed.) 1935: 60, Pl. 35; Borghouts 1978: 79. For the holes (qrrwt) in the head, see: CT VI, 410c [777]; Faulkner 1977: 304; Carrier 2004b: 1736-1737.

${ }^{133}$ The influence exerted by the divine world upon the life of the individual is attested in the concept of ' $\breve{S} 3 y$ ', 'destiny'. For the theology of will and New Kingdom personal piety texts indicating that the life and destiny of an individual is in the hands of god, see: Assmann 1995: 196-197.

${ }^{134}$ For male and female dead and enemies in another magical incantation, see: P. BM EA 10059, XIII, 4-5; Leitz 1999: 79.

${ }^{135}$ Borghouts 1978: 35. In the subsequent paragraph, the patient states that if all these influences remove themselves, he will not keep saying: break out, vomit, or perish. For other examples of the phrase 'break out' in magical texts, see: Borghouts 1978: 51-83, 91-97. Vomiting is mentioned in the recitation of P. Ebers 131 $(30,16)$ as a treatment to get rid of ' $w h d w$ ', which has come forth from excrement. The incantation reads: $B e$ spat out! Be vomited out! Perish just as you came into being! See: Ghalioungui 1987: 42; Ritner 1993: 82. For perish as a protection in a spell, see: Raven 2012: 92. In another conjuration the pain-substances (whdw) have come forth from a tumour; see: Borghouts 1978: 34; Strouhal, Vachala, Vymazalová 2014: 50.

${ }^{136}$ Strength ' $r w \underline{d}$ ' and soundness ' $w \underline{d} 3$ ' are two of many prototypical qualities attributed to the bones in the Coffin Texts. For 'rwd $\underline{d}(w)$ qsnw', see: $C T$ III, 196d [218]; Faulkner 1977: 173. For ' $r w \underline{d} n$ qsnw=j', see: $C T$ V, 222h [407]; Faulkner 1977: 58, n. 17. For 'w $w 3$ 3(w) qsnw', see: $C T$ VII, 452g [1119]; Faulkner 1977: 164.

${ }_{137}$ P. Prisse 4, 9 (1. 17); see: Allen 2015: 168-169. The painful suffering of the bone is probably regarded as an antonym to soundness and health.

138 P. Amherst 1; P. Berlin 3023, B1 53-56; Parkinson 1997a: 60; Allen 2015: 244.

139 Lichtheim 1973: 171; Allen 2015: 244. 
In Papyrus Leiden I 348, the malign dead male and female inflict pain ${ }^{140}$ on the revered deceased, as the text reads: Backwards, enemy, friend, dead male, dead female and so on, who cause this pain (mrt) to $N N$, son of $N N !^{141}$

\section{PAIN HEALING}

In prescription twenty-four of the medical texts of Papyrus Kahun, the expression used to heal pain is ' $d r t j 3 w p w m j d t$ '. ${ }^{142}$ The verb ' $d r$ ', 'remove' is used to describe the act of healing pain. In Papyrus Ebers, a section reads: The beginning of a book on the driving out of pain-matter ( $h b h b$ whdw) in all body parts of a man. ${ }^{143}$

Although dead people have malign aspect as inflictors of pain and they are frequently attested as pain inflictors, they can expel the physical pain of the living. In a letter of the First Intermediate Period, a husband called Merirtyfy writes to his dead wife Nebetiotef, addressing her with emotional intimacy saying: Fight on my behalf and guard my name! I did not muddle a spell before you, while I was perpetuating your name upon earth. Remove the pain of my body $\left(d r m r t^{144} n t h{ }^{\ulcorner} w=j\right) .{ }^{145}$ This letter ascribes the dead wife the ability to expel pain from the whole body.

\section{DISCUSSION}

The discussion of the etymology of pain aims at examining the vocabulary and linguistic expressions as well as the verbs, which precede words for pain in different contexts in the corpus of this article.

\section{ETYMOLOGY OF PAIN FEELING}

In the context of the psychological aetiology of pain the word ' $m r$ ', 'pain', is frequently used to describe the metaphoric pain in the heart of humans. If the heart is painful $(m r j b)$ for someone it grieves and feels compassion for that individual. The hearts of humans feel pain to each other, though they invoke the gods to alleviate their pain. As for the heart of gods, it is being painful for the sacred eye $(m r j b n w \underline{d} 3 t)$.

On the other hand, the 'painful heart' is used as a metaphoric expression for sadness and helplessness, which is attested in the Story of Sinuhe. In only one occurrence, in spell 655 of the Coffin Texts, the word ' $3 h w$ ' is used to describe pain in the hearts probably of the living people who are immediately mentioned afterwards. The usage of ' $3 \mathrm{hw}$ ' in this context designates pain as a misery and suffering.

${ }^{140}$ Dead male and female inflict night blindness and veiling of the eye; see: P. BM EA 10059, incantation

22, VII, 8-9; Leitz 1999: 64. See also: P. Ebers 385 (60, 16-61, 1); Ghalioungui 1987: 114.

141 P. Leiden I 348, rt. 6, 4-5; Borghouts 1970: 21.

142 P. Kahun VI, 1, page 3, prescriptions no. 24; see: Griffith 1898: 9, P1. 6, 1. 8.

143 P. Ebers 103, 1, 856 a (103, 1-2); Ghalioungui 1987: 230.

144 The determinative of the word ' $m r t$ ', 'pain' takes the shape of a Sethian animal; see: Wente 1975-1976: 596.

145 Szpakowska 2003: 24, 186; Wente 1975-1976: 596-598, n. i. 
The word ' $m r$ ' is frequently associated with the pain feeling of the gods. Thus, it is used to express it in four attestations. In spell 37 of the Coffin Texts, in particular, it is mentioned twice as ' $m r$ ', 'sore' and ' $m r t$ ', 'pains'. ${ }^{146}$ In the Incantation of Isis and the Name of Re, it is used in a negative context with the meaning of 'great pain' referring to the unbearable pain of the sun god resulting from a sting of a scorpion. On the other hand, the noun ' $m r$ ' is used after the verb ' $\check{n} n$ ' to express psychological pain in a letter to the dead.

In only one occurrence, the verb ' $m n$ ' is used to state that the head of god J3hsy is paining him. It is also used as a verb in a social context, in the Tale of the Eloquent Peasant with the meaning of 'feel pain'. In the Lamentation of Sasobek, the noun ' $m n w$ ' is used, in a psychological context, to express pain (on the earth) resulting from imprisonment. It is frequently used in Papyrus Kahun to designate physical pain in all the body parts. In an obscure stanza of the Lament of Ipuwer, the word ' $m n t$ ' is used to describe the pain of his body. ${ }^{147}$

In only one occurrence, the word ' $s w n$ ' is used in a social context in the Lament of Ipuwer to express the pain of the starving officials.

The Egyptian language provides specific words to express the pain of childbirth,

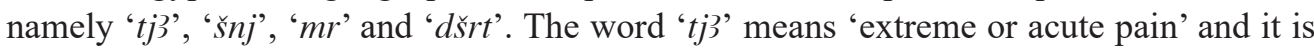
specifically used to express physical pain.

\section{ETYMOLOGY OF PAIN INFLICTION}

The word ' $m r$ ' is frequently associated with the pain infliction of the gods. It extensively describes the places and tools used by different gods to inflict their pain in the Netherworld. These tools and places are consistent with the study of divine pain infliction with the aim of revealing their effect on those who are inflicted. Painful and dangerous places in the afterlife hurt the deceased and have malign effects. Therefore, he has to avoid them. Thus, the word ' $m r$ ' and its derivatives describe the house of Bapef, the painful western darkness ( $k k w$ mrw jmntyw), the trap with painful knives $(m r d m w t)$, the finger of the slayers of Osiris ( $\left.m r w d \underline{d} b^{\complement} w\right)$, the sharp arrows of Sekhmet ( $\left.m r s p d w s ̌ s r w\right)$, the flame of the cobra goddess $(m r t n s(r))$, and the sting of the scorpion goddess Hededet $(H d d t m r(w) j r n=k s t$ $m r . t j) .{ }^{148}$ It also designates the physical pain inflicted by Amun on his offenders. Its plural form ' $m r w$ ' designates the pain inflicted by the enemies of Osiris.

In two occurrences, the word ' $m r$ ' is used in a psychological context. In the Story of the Shipwrecked Sailor, it is used as an adjective to describe the memory of something painful ( $h t \mathrm{mr}$ ). In a letter to the dead, on Hu bowl, ' $m r$ ' is used as a noun to express the pain made by an anonymous offender who had withheld from the writer's daughter her fair share of the inheritance. In the Tale of the Eloquent Peasant, ' $m r$ ' designates the physical pain of the peasant resulting from the beating of his limbs. The feminine derivative ' $m r t$ '

\footnotetext{
146 Faulkner 1972a: 111.

147 P. Leiden I 344, 10, 1. 12; see: Quirke 2004: 147.

148 Carrier 2009: 166.
} 
in Papyrus Leiden I 348, designates the pain infliction on the revered deceased by the malign dead males and females.

In only one occurrence, the noun ' $j h$ ' describes the pain of a portal in the House of Osiris in the Netherworld. In the Tale of the Eloquent Peasant, the noun ' $3 h w$ ' designates the pain, which Maat causes. In a single case, in the Imy- $d w 3 t$, one of the guards of the sun god is named ' $n k n w$ ', 'who causes pain (to the enemies of the sun god)'.

The words ' $q s n$ '149 and ' $q s n t$ ' are frequently used in social context to describe the painful years of famine and the chaos in the land of Egypt caused by the invasions. The noun 'qsn' describes the vile Asiatic invaders and their vile places. Consequently, the nouns ' $q s n$ ' and 'qsnt' are also used to mean 'troubling by foes' and 'trouble or misfortune' respectively. Furthermore, the adjective 'qsnt', 'painful' describes the defeat of the enemies of the king. On the other hand, the adjective ' $q s n$ ' is used to describe a way, which lacks water.

In the statement ' $m 33=f \mathrm{rh} m \mathrm{hm} 3 \mathrm{ht} \mathrm{m} m \mathrm{~m} t$ ' ignorance is compared to what is painful. The context of this text refers to self-inflicted pain (mnt) that could be psychological or emotional caused by ignorance. In contrast, in the Teaching of the Vizier Ptahhotep ' $m n(w)$ ' is used to describe the pain of the old age.

The noun ' $w h d$ ' and its female derivative ' $w h d t$ ' are used to mean the physical infliction of pain-substances in a magical incantation. On the other hand, 'whd' is used in a psychological context, in the Lamentations of Khakheprre-soneb, to describe the pain resulting from being silent.

\section{ETYMOLOGY OF PAIN HEALING}

The Egyptian language provides several verbs, which are used in contexts expressing healing, suppressing and removing the feeling of pain. In the Debate between a Man and his $B a$, the verb ' $s d h$ ' is used in a psychological context before the noun ' $3 h$ ' to mean 'suppress the pain (of life)'. This verb usually precedes something malign or evil to minimise its harm. Thus, it also means 'bring low the arm of the evildoer'. ${ }^{150}$

In the Lamentations of Khakheprre-soneb, the verb ' $d r$ ' is also used in a psychological context before the noun ' $m n$ ' to mean 'remove the pain (through the heart)'. It is also used in the Ptolemaic Lamentations of Isis and Nephthys, to mean drive out all the pain which is in the hearts of the two goddesses $(d r=k 3 h w$ nb nty $m j b w=n)$. In spell 32 of the Coffin Texts, it is used to mean 'dispel the pain $(j h)$ of Osiris'. In chapter 130 in the Book of the Dead, it precedes the compound word ' $m r$ $j h$ ' and gives the meaning to the removal of the sore pain of the Eye of Horus. In Kahun Papyrus, the verb ' $d r$ ' is also used with the noun ' $t j 3$ ', 'acute pain'. In a letter to the dead, it means removing the pain of the body ( $d r$ $m r t n t h^{\top} w$ ). In a religious context, the noun ' $m r$ ' is used two times to describe the pain of childbirth, which is removed by Isis, Montu, Khonsu and the gods of heaven and earth.

${ }^{149}$ For 'qsn', 'painful', see: $W b \mathrm{~V}, 69,6-7$. For 'qsn', 'be in pain', see: $W b \mathrm{~V}, 69,9$; Chassinat 1910-1939: $132,164$.

150 Urk. IV, 968, 17. 
Furthermore, it appears in a text on the block statue of Amenirdis before the noun ' $m n t$ ', 'pain'. This verb is usually associated with dispelling or removing something unpleasant or malign. For example, removing fury from the heart of the god ( $d r \check{s} p t-j b m j b n n t r)$ against the deceased. ${ }^{151}$ Furthermore, it is used in connection with removing evil, as Thoth is the one who drives away evil $(d r \underline{d w t}){ }^{152}$ It may also find an explanation in statements, which express the removal of psychological pain from the heart, ${ }^{153}$ and physical pain from the body, ${ }^{154}$ as pain and anger are both negative feelings. In Papyrus Ebers, the verb ' $h b h b$ ', 'drive out' precedes ' $w h d w$ ', 'pain-matter'. ${ }^{155}$ In this occurrence, the verb ' $h b h b$ ' is sometimes translated as 'to drive out'. ${ }^{156}$

In chapter 102 in the Book of the Dead, the verb ' $n h m$ ', 'save, rescue' is used to express that the deceased may save the god from the pain ' $m r$ ' in his body parts, stating that it would do him evil. In the Lament of Ipuwer, the same verb is used in a social context before the noun ' $w h d t$ ', 'pain', which emphasises that pain is a malign feeling. Therefore, this verb is used by the meaning of saving from something evil. In the Story of Sinuhe, he says: The determination that saved me from death ( $\mathrm{hhm}$ wj $\mathrm{m}^{\mathrm{C}} \mathrm{m}(\mathrm{w}) \mathrm{t}$ ) has to be good. ${ }^{157}$ It is used in chapter 130 in the Book of the Dead, as the deceased says: I rescue Re from Apophis every day $\left(n h m=f R^{\ulcorner} m\right.$ - $\left.^{\ulcorner}{ }^{c} p p r^{\ulcorner} n b\right) .{ }^{158}$ In a similar context, the verb ' $\check{s} d j$ ', 'to rescue' or 'save' is used with the pain of childbirth ( $m r m s w)$.

In spell 32 of the Coffin Texts, the verb 'sndm', 'calm' is used in a religious context before the noun ' $j h$ ', 'pain (of Osiris)'. It is a causative verb with different good meanings, namely make happy, pleasant, content and give pleasure to someone. ${ }^{159}$ It also means ease suffering like pain. Therefore, it indicates that pain produces an agonising feeling, which should be calmed.

On the stelophorous statue of Mentuemhat, the verb 'shrj' ${ }^{160}$ precedes the noun ' $w h d$ ' to mean drive (pain) away. This verb also means remove and exorcise ill, ${ }^{161}$ and drive away foes, ${ }^{162}$ which demonstrates that pain is harmful and unpleasant.

${ }^{151}$ Faulkner 1985: 17; Quirke 2013: 31.

152 Faulkner 1985: 181; Quirke 2013: 468.

153 See: P. Berlin 3008, 3, 4-3, 7; see: Faulkner 1934: 339, Pl. 2; Lichtheim 1980: 118.

${ }^{154}$ In a text on the Twenty-fifth Dynasty stelophorous statue of Mentuemhat at Cairo Museum (CG 42237), he addresses Amun saying: I bow down to your name, may it be my physician, may it remove my body's illness, may it drive pain away (from me) ( $\left.d r=f m n t n w h^{\top} w=j \operatorname{shrj}=f n w h d\right)$; see: Lichtheim 1980: 30.

${ }_{155}$ P. Ebers 103, 1, 856 a (103, 1-2); Ghalioungui 1987: 230.

$156 \mathrm{~Wb}$ II, 488, 1 (Schmerzen vertreiben); Faulkner 1972a: 158.

157 Sinuhe B 203; Allen 2015: 123.

${ }^{158}$ Faulkner 1985: 119; Carrier 2009: 483.

159 Faulkner 1972a: 235; Hannig 2006: 2274.

${ }^{160}$ For the verb 'shrj', 'drive away', see: Faulkner 1972a: 238; Hannig 2006: 2290.

161 Urk. IV, 240, 5.

162 Urk. IV, 209, 17. 
The aetiologies of pain can be divided broadly into four types, namely: psychological, social, religious and physical. Each type has its own causes, symptoms and consequences.

\section{PSYCHOLOGICAL AETIOLOGY AND SYMPTOMS OF PAIN}

Psychological pain is usually inflicted by the negative feelings of despair, depression, and helplessness on the living individuals. This type shows the emotional effect of pain. In this context, pain hurts the feelings, as it can be inflicted using painful words for instance. This perception of pain is frequently expressed in Egyptian literature and specifically in the Lamentations of Ipuwer, Khakheperre-soneb, Sasobek, the Tale of Sinuhe, the Debate between a Man and his Ba, the Story of the Shipwrecked Sailor and the Report of Wenamun. In these literatures, pain is inevitable and can be a malefic force that disables those who are inflicted to the point of making their lives miserable.

In these occurrences, pain inflicts the soul and the heart causing grief or compassion. In the Debate between a Man and his Ba, the latter causes his feeling of pain because of its inability to suppress pain. A man known that his $b a$ will witness the weighing of the heart on the day of judgement. Instead of alleviating the pain of life, he addresses his $b a$ to sweeten the West ${ }^{163}$ and make death easy for him. But death will not be sweetened and even if the $b a$ could do it, because of its incredible powers, it will not, and therefore his feeling of pain is never ending.

The inflicted pain of the heart is metaphorically expressing compassion, pity or disappointment. Many Middle Kingdom texts in this article present the heart as the source of pain. The Lamentations of Khakherre-soneb is a monologue spoken by a priest to his own unresponsive heart, stating that his heart is responsible for his sufferings and expressing his personal despair and his inability to control his own heart.

Thirst, imprisonment and bad treatment are reasons for psychological pain. Speechlessness is another burden of psychological pain, ${ }^{164}$ and particularly at a time of disasters. Although the metaphor of silence expresses the individuals' trust in the justice of deities, which releases them from any negative feeling, ${ }^{165}$ silence here demonstrates pain. This contradicts with the perception of personal piety ${ }^{166}$ which implies that the silent individuals willingly submit themselves to the gods' volition. ${ }^{167}$ The occurrences of speechlessness in this article come from Middle Kingdom literary texts regarding the theme of national distress and chaos. Therefore, the silence of both Khakheprre-soneb and Ipuwer indicates their inability to express their burden because of that distress, which results in their feeling of pain.

\footnotetext{
163 Sweetening the West indicates that the West is a painful place; see below.

164 Ockinga 1983: 88-95.

165 Assmann 2003: 235.

166 Jan Assmann argues that the personal piety dates in its origin to the Eighteenth Dynasty as early as the times of Hatshepsut, Thutmose III and Amenhotep II and its roots should be looked before First Intermediate Period; see: Assmann 1989: 69.

167 Assmann 2003: 235.
} 
Ignorance is another symptom of pain infliction. Knowledge and ignorance are compared with positive outcomes and what ends in pain. Therefore, ignorance resembles illness as a cause of pain that distresses the life of the ignorant to be miserable, as he does everything hateful to the point that he is reprimanded every day. ${ }^{168}$

\section{SOCIAL AETIOLOGY AND SYMPTOMS OF PAIN}

The social aetiology of pain is expressed in many literary texts and specifically those, which describe the lamentable state of Egypt, with socially inconvenient circumstances, long years of famine and distress as painful due to the lack of food and crops. These circumstances create painful feelings of despair and unhappiness, which are attested in specific literary texts of lamentations. They also describe foreign invaders and the social disorder as painful experiences. The pain inflicted by these invaders is emotional and intangible just like the pain they receive.

The Words of Neferty, detail the predictions of a sage man describing the chaotic status of Egypt with persistence concerns about foreign invasion that caused pain to the whole land. ${ }^{169}$ In the Lament of Ipuwer, he laments the condition in Egypt and describes social disorder, reversal of social classes and lack of food. It contains sequences of laments portraying Egypt overwhelmed by chaos and destruction. Then, it progresses into an analysis of the reasons of these disasters, and who takes responsibility for them: the gods, the king, or humanity.

\section{RELIGIOUS AETIOLOGY AND SYMPTOMS OF PAIN}

Deities are not attested suffering the feeling of solitude, ${ }^{170}$ ageing, deprivation, and speechlessness. ${ }^{171}$ This does not conceal the fact that some gods could be ignorant of specific things such as the real name of each god, which was not known to the others. ${ }^{172}$ On the other hand, deities suffer psychological and physical pain and in specific cases, they share similar experiences of pain with humans. ${ }^{173}$ The bodies of deities have materiality, which could be wounded or hurt. Nevertheless, they were susceptible to afflictions like eye diseases, stomach conditions, headache and they feel pain in their body. ${ }^{174}$

Deities, like humans, are vulnerable to a variety of painful afflictions, such as snake bites and scorpion stings, causing everlasting pain. However, the pain that inflicts a divine body does not affect its entirety. ${ }^{175}$ Unlike humans, deities can create remedies to alleviate their pain and cure each other. Thus, Isis made a remedy for Re to remove the pain in his

${ }_{168}$ P. Prisse 17, 4-9 (11. 575-578); see: Allen 2015: 219-220.

169 O'Connor 2015: 161.

${ }^{170}$ Assmann argues that in traditional Egyptian religion, a 'lonely god' could be imagined only in the context of pre-existence, of primordial oneness. In the world that was subsequently created, loneliness was untenable, not only for men but for gods. See: Assmann 2003: 212.

171 Deities have a society, assemblies and hierarchies; see: Meeks 1996: 34-38, 40-46.

172 For knowledge and ignorance of deities, see: Meeks 1996: 94-102.

173 Borghouts 1970: 72, n. 111; Meeks 1996: 65, 212, nn. 109-110.

174 Borghouts 1970: 22, 35, 72, 129.

175 Meeks 1996: 53. 
head. ${ }^{176}$ However, in only one attestation, the deceased himself can alleviate the pain of specific gods, like Osiris or Re through spitting on the inflicted organs, ${ }^{177}$ but remedies for the pain of humans evidently differ from those of deities.

The causes and motivations of the pain inflicted by the deities notably vary. They inflict pain through stings with the purpose of overthrowing Apophis, the enemy of Re. They also cause pain and spit painful flames to protect the sun god in the Netherworld. They may inflict pain to defend the deceased against his enemies. The pain inflicted by them, in specific occurrences, is also attributed to their mythologies, namely the Contendings of Horus and Seth and the Myth of Osiris. In other cases, this pain is regarded as a retribution and punishment for the transgressions of the living individuals, such as the pain inflicted by Amun-Re. However, he is petitioned to alleviate pain and drive it away. This reveals the ambivalent nature of the god. This ambivalence can be attested in a text dating to the Ramesside period, presenting Amun-Re as a healer and Great of punishment, ${ }^{178}$ mightier than Sekhmet like a raging fire sublime in mercy, caring for those who praise him, who turns (from his wrath) to heal the suffering. ${ }^{179}$ It is clear that Amun-Re here is a healer for those who suffer. ${ }^{180}$ Thus, he gives life and brings death, preserves and destroys reflecting his unpredictable and malicious side. The petition to the god as a healer of pain shows the individuals' closeness to him and their personal piety. ${ }^{181}$ Thus, the inflicted devotees find a necessity to proclaim their personal experience of pain with their personal god.

In other occurrences, the deceased individuals suffer pain inflicted by the deities in the Netherworld. Besides the challenges, which the deceased face at gates and caverns, they were susceptible to threats like tortures and painful deaths, which were envisioned to be inflicted by frightening entities in the Netherworld.

The role of specific benevolent deities as pain inflictors raises the question about their motivations in inflicting pain on the deceased people. In some cases, these gods adopt

176 P. Ebers 247 (47, 5-10); cf. P. Ebers, 242 (46, 10-16); 243 (42, 16-19); 244 (46, 19-22); 245 (46, 22-47, 1); 246 (47, 2-5). In these texts remedies are made by Re, Shu, Tefnut, Geb, and Nut for themselves or each other; see: Ghalioungui 1987: 81-82.

${ }^{177}$ For spitting on organs as remedy in Egyptian magical texts, see: Ritner 1993: 79-80, 90. For spitting as a folk-medicine for healing, see: Faulkner 1930: 171, n. 4; see also: PT 684, §§ 2055-2056; Faulkner 1969: 294.

178 The Egyptian word for punishment in this text is ' $b 3 w$ '. For the meaning of ' $b 3 w$ ', 'anger', see: Wente 1967: 46, n. (g); Gardiner 1962: 62, n. 3.

179 Assmann 1995: 203-204. A late Ramesside text, on the Papyrus Bibliotheque Nathionale (197, II), shows the role of Amun-Re as to the health and welfare of the scribe of the necropolis Tjararoy; see: Wente 1967: 43, no. 11. The stela of Nebre and his son Khay, which dates to the Nineteenth Dynasty, reign of Ramesses II, is an example of a votive stela to thank Amun-Re for healing and saving the life of Nebre's son, Nakhtamun, who was very sick and was thought to have offended Amun; see: KRITA III, 653-655; Lichtheim 1976: 105-107; Sadek 1987: 226-227.

${ }^{180}$ In Papyrus Leiden I 370, in a letter of the scribe of the great and noble necropolis, Djehutymes to the scribe Butehamun and the chantress of Amun Shedemdua, he says: And you shall tell Amun to remove this illness which is in me; see: Wente 1967: 28, no. 5.

${ }^{181}$ The personal piety is regarded as one of several various coping strategies that were provoked during different crises and other personal strokes of fate. For Ramesside texts of 'personal piety' showing personal relation and closeness to Amun-Re in the Theban theology, see: Assmann 1995: 200; Brunner 1982: 951; Becker 2011: 63 . 
the qualities and characteristics of other malevolent deities. Anubis, Horus Mekhentirty act like the slayers of Osiris who inflict pain using their sharp fingers. Although the two gods are frequently attested as benevolent gods, they have malign characteristics due to their ambivalent nature. Anubis, for example, as a malevolent god, spears and traps the deceased in the place of the wounded one, where the deceased escapes from the god's trap. ${ }^{182}$

Although benevolent deities are attested as pain inflictors, they are also attested as healers of pain. Thus, they can be summoned by other gods to alleviate various kinds of pain including that of labour. In a different context, the name of specific gods is petitioned to relieve physical pain. This indicates an intimate closeness to deities and stresses the notion of a 'personal deity' who comes to mean everything for a certain worshipper or devotee. ${ }^{183}$ Healing pain was not only restricted to Egyptian deities, but it was also attributed to foreign deities, namely Reshep ${ }^{184}$ and Ishtar.

\section{PHYSICAL AETIOLOGY AND SYMPTOMS OF PAIN}

The physical aetiology of pain and its symptoms are described in medical papyri with prescriptions in most cases. These papyri describe pain in the different body parts. Aging is another cause of physical pain for the human body. In medical texts, there are a group of prescriptions against belly-pains caused by demoniacal diseases. ${ }^{185}$ Malign demons are frequently mentioned in medical papyri as external causes of fatal diseases. ${ }^{186}$ Demonic pain inflictors have genders like humans. ${ }^{187}$ These demons have the ability to attack humans and cause harm and therefore, specific magical incantations are recited to repel their attacks. ${ }^{188}$ Demons, as malefic creatures, can inflict painful diseases. A disease called ' $t m y t$ ', ${ }^{189}$ possibly a skin disease, is inflicted by a demon hurting the bones and blood vessels and causing abdominal pain. ${ }^{190}$

${ }^{182}$ CT VI, 47c-d [481]. The text reads: O Anubis, Lord of Asyut(?), who spears and traps in the place of the

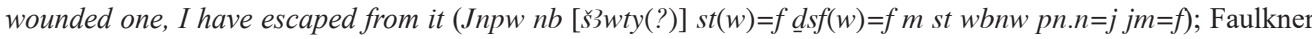
1977: 126; Carrier 2004a: 1186-1187.

${ }^{183}$ Hornung 1982: 236.

${ }^{184}$ After the reign of Amenhotep II, Reshep appears as a god of popular religion. He is the god who 'hears prayers' ( $s \underline{d} m n h w t)$, and many individuals start to approach him for pleas and particularly at Deir el-Medina; see: Giveon 1980: 144. Åsa Strandburg argues that the single gazelle's head on Horus cippi and the forehead of Reshep refers to the apotropaic qualities of Reshep and his general association with healing; see: Strandburg 2009: 140 .

185 Grapow 1958: 255-258; Ghalioungui 1987: 75-76.

${ }_{186}$ P. Ebers 209 (43, 4-8); 854e (99, 14-17); 855y (102, 14-15); Ghalioungui 1987: 72, 219, 228.

187 This is attested in incantation 14 of London Medical Papyrus, as it reads: The legs tremble [...] like women who come with pain-demons male and female ( $w h d w w h d t)$; see: P. BM EA 10059, V, 1-2; Leitz 1999: 60.

${ }^{188}$ P. BM EA 10059, V, 3; Leitz 1999: 60. The concept of demonic pain may indicate that the deceased receives bodily wounds. In the Coffin Texts, the deceased, who is identified with Osiris can ease and alleviate his own wounds ( $s q q b(w)=j[n] s p w)$; see: $C T$ III, 322c [239]; Faulkner 1973: 189; Carrier 2004a: 586-587.

189 For this disease, see: Leitz 1999: 61, n. 91.

${ }^{190}$ Hannig 1995: 923. 


\section{THE EFFECT OF PAIN ON THE DECEASED AND LIVING INDIVIDUALS}

Although life is full of misery, the Egyptian religious books of the afterlife, state that the painful places are in the Netherworld. Therefore, the deceased has to evade a series of painful and dangerous places in the Hereafter. ${ }^{191}$ These places are closely associated with the houses of specific gods, the Netherworld and the West, where pain is generated. The houses are attributed to gods whose nature is malevolent like Bapef, or benevolent like Osiris indicating the ambivalent nature of the latter who turns to be malevolent. The highly unpleasant nature and the foul smelling in the house of Bapef generate pain feelings. On the other hand, the flames, destructive heat, and blaze cause pain when the deceased passes a portal in the house of Osiris. Through the study of these places, it is explicit that pain is inflicted there by malign entities or guardians under the command of these gods.

The painful places raise the question about their association with pain infliction and their designation as places of pain. In the Coffin Texts, the West, which is the realm of Osiris, is curiously described as being painful. The West is the place where the sun dies bringing about darkness, evoking the return of the primordial chaos that prevailed before the birth of the creator god. Furthermore, the western horizon is the beginning of the deceased's journey from death to life. Unlike the painful West, the East is the place where the sun is reborn, and the forces of darkness are defeated. Therefore, the deceased must undergo the painful afflictions of the West to prove worthy of the Iaru-fields of Osiris. The deceased is given power over the West ${ }^{192}$ to overcome all difficulties in this region, and this may explain the designation of the West as a painful place. Although specific gods, with malevolent characteristics, are associated with painful regions in the Netherworld, other gods are invoked to ward off the pain there. In one case, the fathers and mothers of the gods are invoked to save the deceased from the trap with painful knives implying its bad and harmful effect.

Divine pain inflictors are malevolent or benevolent deities who cause painful diseases or injuries. The pain inflicted by deities is attested in various texts including the Pyramid Texts, the Coffin Texts, the Books of the Dead and Imy- $d w 3 t$ as well as literary texts. In one occurrence, there is a link between the removal of pain-substances and bad effects on one hand, and the patient's offerings to the gods, on the other. Thus, the consequences of pain infliction could be deflected by threatening the gods. In other words, the offering to the Abydene gods is ceased in order that the pain infliction would be removed. This clearly shows a threat to the benevolent Abydene gods and raises the probability that those gods are somehow involved as pain inflictors whose infliction is unbearable and agonising to the extent that they are threatened. In the Pyramid Texts ${ }^{193}$ gods could be threatened and warned for various reasons, but this is the only attested threat because of the inflicted pain.

191 Zandee 1977: 167-173.

192 The conclusion of spell 508 in the Coffin Texts: the West is yours (nnk jmnt) demonstrates that the purpose of this spell is to give the deceased power over the West; see: CT VI, 94i [508]; Faulkner 1977: 143; Willems 1996: 187.

193 PT 310, § 492; 485, §§ 1027-1028; Faulkner 1969: 96, 172. 
Maat who symbolises justice and truth acts against her principles and turns out to be a grasper and pain-maker against the 'eloquent peasant'. The latter addresses Maat in a way that can be described as a transgression against a divine symbol. He suffers severe pain commensurate with the extent that he had offended Maat. This evokes the above-mentioned magical incantation in which the patient threatens the Abydene gods.

Specific gods act as pain inflictors against the living individuals. The pain they cause could be metaphoric ${ }^{194}$ or real. Amun-Re, as a benevolent god, can also inflict physical pain on humans because of their transgressions and sins.

The living and dead are also petitioned to alleviate pain, however with different approaches. The alleviation of pain by the living is regarded as charitable and beneficent work with the aim to be released from guilt in the final judgment and gain the praise of gods. Only pious dead can ease pain unlike the malign dead who are attested as pain inflictors. However, in some cases the deceased inflict pain to defend themselves against the evil creatures in the Netherworld.

Like deities and demons, living and dead individuals can inflict painful diseases and wounds. Although living people can inflict pain, they also heal it. In contrast, deceased individuals are frequently attested as pain inflictors in religious and magical texts. Their pain infliction is more dreadful than that of the living. ${ }^{195}$ This is probably because the dead have malefic forces in comparison to the living.

\section{CONCLUSIONS}

The religious aetiology of pain and its phraseology are extensively attested in this article more than the other aetiologies and stimulations. The frequent occurrences of this aetiology and its vocabulary has many reasons and, notably, the variety of its sources. The books of the afterlife, the magico-religious papyri and other private monuments provide many attestations of that type of pain. Another important reason is their association with divine punishment represented in the use of painful places and tools by the deities to inflict pain on the living and dead individuals. The ambivalent character of specific gods, as inflictors and healers of pain, further increases the number of occurrences of that kind of pain. Furthermore, deities are attested suffering physical and psychological pain on one hand, and meanwhile they inflict pain on one another, the living and dead individuals, on the other hand.

The Egyptian language has many words for pain that appear to be interchangeable with the same semantics, while having slightly different shades of meaning. One of the reasons

\footnotetext{
194 A group of New Kingdom stelae is inscribed with a text reads: Seeing darkness by day ( $m 33 \mathrm{kkw} m \mathrm{hrw}$ ). Metaphorically, this affliction indicates a loss of contact with the deity, that is a spiritual blindness, whilst the dedicator is alive, or, it indicates that the dedicator, when dead, cannot see the deity in the afterlife; see: Bell 1985: 54-55, n. 168; Borghouts 1982: 7; Galán 1999: 18-30.

195 In some cases, this infliction is regarded as a self-defence. Therefore, in chapter 43 in the Book of the Dead the deceased says: I am a flame, the son of a flame, to whom was given his head after it had been cut off; see: Faulkner, Goelet 1998: 51; Faulkner 1985: 63.
} 
to have these synonymous words is to enhance the flexibility of the Egyptian language to better express the various feelings of pain. Other reasons for having a variety of words for pain are the derivations, such as ' $m n$ ', ' $m n t$ ', ' $m n w$ ', ' $m r$ ', ' $m r t$ ', ' $m r w$ ', and the variants such as ' $3 h$ ', ' $j h$ ', and ' $3 h w$ ', ' $j h w$ '. The level of pain provides another variety of words, namely, the noun ' $t j 3$ ', 'acute pain' and the compound noun ' $j h \mathrm{mr}$ ', 'sore pain'.

All the verbs, which precede words for pain and particularly in a context of pain healing, clearly demonstrate that pain is a malign and unpleasant feeling that should be healed or repelled. This includes the physical and psychological pain as well as the pain of gods.

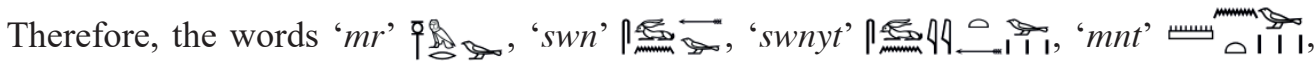
' $m n w$ ’ with the sparrow, the bad bird with its connotations of suffering, wickedness, and evil. ${ }^{196}$

The words ' $\check{n} n j$ ', ' $d \check{s} r t$ ' and ' $t j 3$ ' are specifically used to designate physical pains and they were never used to express psychological or divine pain. The words ' $q s n$ ' and ' $q s n t$ ' primarily describe physical pain, where the patient is unable to open his mouth, difficulties, disasters, troubles ${ }^{197}$ and a lack of supply. However, they were never used to express the religious aetiology of pain. This demonstrates that the Egyptian language has its own phraseology to express pain with extensive use of the word ' $m r$ ' and its derivatives ' $m r t$ ' and ' $m r w$ '. These words are employed to express divine pain in the first place. However, they are also attested in psychological and social contexts. The frequent occurrences of the word ' $m r$ ' and its derivatives in this article is due to the fact that it is closely associated with grief, emotional as well as psychological and physical pain and notably that of the gods. It is frequently associated with the noun ' $j b$ ' to express a feeling of compassion and pity. It is also used to describe pain of childbirth in two occurrences.

The Egyptian language provides metaphors for the feeling and infliction of pain. This is described within different expressions, namely: ' $m r j b$ ', 'pain of the heart', ' $j b$ qn $m s t$ $q s n t$ ', 'a brave heart amid pain' and ' $j b=f m r(w)$ ', 'his heart being painful'. Thus, feeling pain in one's heart is having pity, compassion and sympathy for someone else. It happens to one's heart because of being affected by the condition of other people. According to this expression, pain has a positive connotation unlike its common negative one. On the other hand, the red colour ( $d \check{s} r$ ) is used as a metaphor to describe a woman ( $h m t d \check{s} r t)$ who has undergone multiple childbirth. This evokes the metaphoric expression ' $d \check{s} r \mathrm{jb}$ ', 'furious' (lit. red-hearted), as both fury and pain are generally negative emotions. ${ }^{198}$

There are various types of pain infliction in ancient Egypt, some good and protective while others negative and malefic. The religious, magical, medical and literary texts differentiate

196 David 2000.

197 The word '3hw', 'pain' indicates trouble in the sense of shortage in the Teaching for King Merikare, as the text reads: '3hw $m$ mw', 'lacking in water'; see: Lichtheim 1973: 104; Parkinson 1997a: 223, 34 (P 91). In the Teaching of the Vizier Ptahhotep, the word ' $3 h w$ ' occurs with a causative ' $s$ ' as ' $s 3 h w$ ', which is translated by Lichtheim as 'deprived'; see: Lichtheim 1973: 72.

$198 \mathrm{~Wb}$ V, 490, 6; Siut I, 230; Griffith 1889: P1. 4. 
and classify diverse types of pain, which have their own phraseology. This differentiation allows the authors of these texts to use precisely the right words according to the situation and the context demonstrating the aetiologies, feelings and consequences of pain. It demonstrates the flexibility and versatility of the Egyptian language to express the different unpleasant feelings of pain.

For instance, the pain inflicted by the deities on the deceased individuals has a different phraseology, as they use weapons, stings, fire, painful places and zoomorphic incarnations of wild animals to inflict pain. Their techniques of infliction cause severe pain and in other cases they ward off the attacks of enemies and evil creatures in the Netherworld. Therefore, the pain inflicted by them is treated in a different way. The pain inflicted by demons and malign deceased is usually repelled by the recitation of magical spells. The pain inflicted by the living individuals, however, is rarely attested in the corpus of this study. This is probably because it is regarded as a transgression. This is attested in the declaration of innocence in the Book of the Dead, where the deceased states: I have not done what the god abhors, I have not maligned a servant to his master, I have not caused pain (smr), ${ }^{199}$ I have not caused tears. ${ }^{200}$ This text declares the innocence of causing pain during the lifetime of the deceased and mimics moral maxims as it indicates that causing pain to someone is an offence.

The diachronic development of pain is demonstrated by the dates of the texts in which pain is stated. In the Middle Kingdom literary texts, pain is closely associated with disasters, such as famines, invasions and chaos. This theme of pain is also attested in the Nineteenth Dynasty Lament of Ipuwer. However, the latter uses a distinctive phraseology with different vocabulary such as the words ' $s w n$ ', ' $m n t$ ', and ' $w h d y t$ '. Furthermore, in the New Kingdom Lamentations of Khakheprre-soneb, the words ' $q$ snt' and ' $w$ hd' are used to describe his pain. On the other hand, the Middle Kingdom literature uses different words, namely ' $m r$ ', '3h', '3hw' and ' $m n$ '.

The phraseology of pain on letters, and notably those of the dead, does not show any diachronic development of using different words for pain. On the other hand, the Middle Kingdom Coffin Texts and the New Kingdom Book of the Dead use the same phraseology of pain and specifically the repeated statement of the adjective ' $m r$ ' and its derivatives.

Feelings and emotions of deities differ from those of humans. Therefore, the divine pain is somewhat distinct from the human pain and notably regarding its infliction and healing. On the other hand, the pain of the gods are partly related to their mythologies, namely the Contendings of Horus and Seth, the Myth of Osiris, and the Incantation of Isis and the Name of Re.

It is evident that when pain is unbearable and intolerable, it drives those who are inflicted to approach a deity offensively. The Tale of the Eloquent Peasant shows that there is no

\footnotetext{
${ }^{199}$ For the causative verb 'smr', 'cause pain', see: Wb IV, 139, 9; Faulkner 1972a: 229; Buck 1948: 116, 13.

${ }^{200}$ BD 125; Lichtheim 1976: 125; Schneider 2013: 117; Karenga 2004: 313.
} 
divine intervention implying that the gods will not intervene to save the innocent peasant. This feeling culminates in the ninth petition, which states that justice and truth cannot be found in this world. ${ }^{201}$ Therefore, the address of the peasant to Maat as a pain-maker indicates his despair and misery bringing about his feeling of pain. It also indicates that he has lost confidence in justice. Thus, the text describes the peasant's sensations and his experience of pain, which profoundly changed his attitude, and beliefs about justice, and the realm of the gods. In a similar context, threatening gods ${ }^{202}$ with a suspension of devotion is likely a response of hopelessness of a disappointed worshipper with the goal of overcoming the unbearable feeling of pain.

\section{Acknowledgments}

It is a pleasure to thank Professor Christopher J. Eyre, University of Liverpool, for commentary on an earlier draft of this paper.

\section{References}

Abbas, E. 2010: The Lake of Knives and the Lake of Fire: Studies in the Topography of Passage in Ancient Egyptian Religious Literature, BAR-IS 2144, Oxford

Allen, J. 2015: Middle Egyptian Literature: Eight Literary Works of the Middle Kingdom, Cambridge

Allen, T. 1974: The Book of the Dead or Going Forth by Day. Ideas of the Ancient Egyptians concerning the Hereafter as Expressed in Their Own Terms, SAOC 37, Chicago

Alliot, M. 1949: Le culte d'Horus à Edfou au temps des Ptolémées 1, BiEtud 20, Le Caire Assmann, J. 1989: State and Religion in the New Kingdom, [in:] Allen, J.P., Assmann, J., Lloyd, A.B., Ritner, R.K., Silverman, D.P. (Eds), Religion and Philosophy in Ancient Egypt, YES 3, New Haven, 55-88

Assmann, J. 1995: Egyptian Solar Religion in the New Kingdom. Re, Amun and the Crisis of Polytheism, London-New York

Assmann, J. 2003: The Mind of Egypt. History and Meaning in the Time of the Pharaohs, Cambridge-London

Assmann, J. 2005: Death and Salvation in Ancient Egypt, Ithaca-London

Barns, J. (Ed.) 1956: Five Ramesseum Papyri, Oxford

Becker, M. 2011: Persönaliche Frömmigkeit - Ein gesellschaftliches Phänomen in der Aufarbeitung von Krisensituationen, [in:] Friese, W., Greve, A., Kleibl, K., Lahn, K. (Eds), Persönliche Frömmigkeit: Funktion und Bedeutung individueller Gotteskontakte im interdisziplinären Dialog; Akten der Tagung am Archäologischen Institut der Universität Hamburg (25. - 27. November 2010), Hephaistos (B) 28, Berlin

\footnotetext{
201 Parkinson 1997a: 56.

202 For a threat against Thoth, see: Meeks 1996: 45.
} 
Bell, L. 1985: Aspects of the Cult of the Deified Tutankhamun, [in:] Posener-Kriéger, P. (Ed.), Mélanges Gamal Eddin Mokhtar 1, BiEtud 97, Le Caire, 31-59

Borghouts, J.F. 1970: The Magical Texts of Papyrus Leiden I 348, OMRO 51, Leiden Borghouts, J.F. 1978: Ancient Egyptian Magical Texts, NISABA 9, Leiden

Borghouts, J.F. 1982: Divine Intervention in Ancient Egypt and its Manifestation (b3w),

[in:] Demarée, R., Janssen, J. (Eds), Gleanings from Deir El-Medîna, EgUit 1, Leiden, 1-70

Borghouts, J.F. 2007: Book of the Dead (39): From Shouting to Structure, SAT 10, Wiesbaden

Breasted, J.H. 1991: The Edwin Smith Surgical Papyrus: Hieroglyphic Transliteration, Translation, and Commentary, OIP 3, Chicago

Brunner, H. 1982: Persönliche Frömmigkeit, [in:] LÄ IV, 951-963

Brunner-Traut, E. 1977: Farben, [in:] LÄ II, 117-128

Bryan, B. 1991: The Reign of Thutmose IV, Baltimore-London

Buck, A. de 1948: Egyptian Readingbook. Exercises and Middle Egyptian Texts, Leiden

Buck, A. de 1949: The Earliest Version of Book of the Dead 78, JEA 35, 87-97

Carrier, C. 2004a: Textes des sarcophages du Moyen Empire égyptien 1, Monaco

Carrier, C. 2004b: Textes des sarcophages du Moyen Empire égyptien 2, Monaco

Carrier, C. 2009: Le Livre des Morts de l'Egypte ancienne, Paris

Carrier, C. 2010a: Textes des pyramides de l'Égypte ancienne II: Textes de la pyramide de Pépy I Ir, Paris

Carrier, C. 2010b: Textes des pyramides de l'Égypte ancienne IV: Textes des pyramides de Mérenrê, d'Aba, de Neit, d'Ipout et d'Oudjebten, Paris

Chassinat, E. 1909: La seconde trouvaille de Deir el-Bahari (5 février 1891) : Sarcophages, Le Caire

Chassinat, E. 1910-1939: Le Mammisi d'Edfou, MMAF 16, Le Caire

Collier, M., Quirke, S. (Eds) 2002: The UCL Lahun Papyri: Letters, BAR-IS 1083, Oxford

Cornelius, I. 1994: The Iconography of the Canaanite Gods Reshef and Baal. Late Bronze and Iron Age Periods (c $1500-1000$ BCE), OBO 140, Fribourg

Cruz-Uribe, E. 1988: Hibis Temple Project. Translations, Commentary, Discussions and Sign List 1, San Antonio

Daressy, G. 1898: Notes et remarques, RecTrav 20, 72-86

Daressy, G. 1910: Neith protectrice du sommeil, ASAE X, 177-179

David, A. 2000: De l'infériorité à la perturbation: l'oiseau du « mal » et la catégorisation en Egypte ancienne, GOF IV/38, Wiesbaden

Deines, H. von, Westendorf, W. 1961: Wörterbuch der medizinischen Texte. Erste Hälfte (3-r), Grundriss der Medizin der alten Ägypter VII, Berlin

Deines, H. von, Westendorf, W. 1962: Wörterbuch der medizinischen Texte. Zweite Hälfte (h-d $)$, Grundriss der Medizin der alten Ägypter VII, Berlin

Edwards, I. 1960: Oracular Amuletic Decrees of the Late New Kingdom 1-2, HPBM 4, London 
El-Sayed, R. 1982: La déesse Neith de Saïs. Documentation 2, BiEtud 86, Le Caire Enmarch, R. 2005: The Dialogue of Ipuwer and the Lord of All, Oxford

Enmarch, R. 2008: A World Upturned: Commentary on and Analysis of The Dialogue of Ipuwer and the Lord of All, Oxford-New York

Faulkner, R. 1930: A Misconstrued Particle in the Pyramid Texts, JEA 16, 171-172

Faulkner, R. 1934: The Lamentations of Isis and Nephthys, [in:] Mélanges Maspero I: Orient ancien, MIFAO 66, Le Caire, 337-348

Faulkner, R. 1969: The Ancient Egyptian Pyramid Texts, Oxford

Faulkner, R. 1972a: A Concise Dictionary of Middle Egyptian, Oxford

Faulkner, R. 1972b: Coffin Texts 313, JEA 58, 91-94

Faulkner, R. 1973: The Ancient Egyptian Coffin Texts I. Spells 1-354, Warminster

Faulkner, R. 1977: The Ancient Egyptian Coffin Texts II. Spells 355-787, Warminster

Faulkner, R. 1978: The Ancient Egyptian Coffin Texts III. Spells 788-1185 \& Index, Warminster

Faulkner, R. 1985: The Ancient Egyptian Book of the Dead, London

Faulkner, R., Goelet, O. 1998: The Egyptian Book of the Dead: The Book of Going Forth by Day. Being the Papyrus of Ani (Royal Scribe of the Divine Offerings), San Francisco

Fischer, H.G. 1964: Inscriptions from the Coptite Nome, Dynasties VI-XI, AnOr 40, Roma Galán, J.M. 1999: Seeing Darkness, ChronEg LXXIV/147, 18-30

Gardiner, A. 1909: The Admonitions of an Egyptian Sage from a Hieratic Papyrus in Leiden (Pap. Leiden 344 recto), Leipzig

Gardiner, A. (Ed.) 1935: Chester Beatty Gift, HPBM 3, London

Gardiner, A. 1962: The Gods of Thebes as Guarantors of Personal Property, JEA 48, 57-69

Gardiner, A., Sethe, K.H. 1928: Egyptian Letters to the Dead: Mainly from the Old and Middle Kingdoms, London

Ghalioungui, P. 1987: The Ebers Papyrus: A New English Translation, Commentaries and Glossaries, Cairo

Gillam, R. 1995: Priestesses of Hathor: Their Function, Decline and Disappearance, JARCE XXXII, 211-237

Giveon, R. 1980: Review Article. Resheph in Egypt, JEA 66, 144-150

Goyon, J. 1978: Hededyt: Isis-scorpion et Isis au scorpion. En marge du Papyrus de Brooklyn 47.218.50 - III, BIFAO 78, 439-458

Grapow, H. 1958: Grundriss der Medizin der alten Ägypter. V. Die medizinischen Texte in hieroglyphischer Umschreibung autographiert, Berlin

Griffith, F.L. 1898: Hieratic Papyri from Kahun and Gurob (Principally of the Middle Kingdom): The Petrie Papyri, London

Griffiths, J. 1988: Intimations in Egyptian Non-Royal Biography of a Belief in Divine Impact on Human Affairs, [in:] Baines, J., James, T., Leahy, A., Shore, A. (Eds), Pyramid Studies and Other Essays Presented to I. E. S. Edwards, EES 7, London, 92-102 Guerry, E. 2007: Controlling Human Suffering: Terminology of Divine Mercy in Ancient Egypt and in Ancient Israel, BACE 18, 109-123 
Gunn, B. 1934: The Berlin Statue of Harwa and Some Notes on Other Harwa Statues, BIFAO 34, 135-142

Hannig, R. 1995: Die Sprache der Pharaonen: Großes Handwörterbuch Ägyptisch-Deutsch (2800-950 v. Chr.), KAW 64, Mainz a/Rhein

Hannig, R. 2006: Ägyptisches Wörterbuch II: Mittleres Reich und Zweite Zwischenzeit, Mainz a/Rhein

Hart, G. 2005: The Routledge Dictionary of Egyptian Gods and Goddesses, London-New York

Hayes, W. 1973: Egypt: Internal Affairs from Tuthmosis I to the Death of Amenophis III, [in:] Edwards, I. et al. (Eds), CAH 2, Cambridge, 313-416

Helck, W. 1970: Die Prophezeiung des Nfr.tj, KÄT 2, Wiesbaden

Hoch, J. 1994: Semitic Words in Egyptian Texts of the New Kingdom and Third Intermediate Period, Princeton

Hornung, E. 1979: Das Totenbuch der Ägypter, Zürich

Hornung, E. 1982: Conceptions of God in Ancient Egypt. The One and the Many, London

Hornung, E. 1990: The Valley of the Kings: Horizon of Eternity, New York

Hornung, E., Abt, T. 2007: The Egyptian Amduat. The Book of the Hidden Chamber, Zürich Hornung, E., Abt, T. 2014: The Egyptian Book of the Gates, Zürich

Janssen, J. 1991: Late Ramesside Letters and Communications, HPBM 6, London

Jüergens, P. 1995: Grundlinien einer Überlieferungsgeschichte der altägyptischen Sargtexte. Stemmata und Archetypen der Spruchgruppen 30-32 + 33-37, 75(-83), 162+164, $225+226$ und $343+345$, GOF 31 , Wiesbaden

Kákosy, L. 1977: Ein literarisch-mythologisches Motiv: Osiris als Gott des Kampfes und der Rache, [in:] Assmann, J., Feucht, E., Grieshammer, R. (Eds), Fragen an die altägyptischen Literatur. Studien zum Gedenken an Eberhard Otto, Wiesbaden, 285-288

Karenga, M. 2004: Maat, the Moral Ideal in Ancient Egypt: A Study in Classical African Ethics, New York-London

Kolta, K.S., Tessenow, H. 2000: „Schmerzen“, „Schmerzstoffe“ oder „Fäulnisprinzip“? Zur Bedeutung von $w h d w$, einem zentralen Terminus der altägyptischen Medizin, ZÄS 127, 38-52

Leclant, J. 1961: Montouemhat, Quatrième Prophête D'Amon, Prince de la Ville, BiEtud 35, Le Caire

Leitz, C. 1999: Magical and Medical Papyri of the New Kingdom, HPBM 7, London

Lesko, L.H., Lesko, B.S. (Eds) 2004: A Dictionary of Late Egyptian 2, Berkeley

Lichtheim, M. 1973: Ancient Egyptian Literature. A Book of Readings I. The Old and Middle Kingdoms, Berkeley-Los Angeles-London

Lichtheim, M. 1976: Ancient Egyptian Literature. A Book of Readings II. The New Kingdom, Berkeley-Los Angeles-London

Lichtheim, M. 1980: Ancient Egyptian Literature. A Book of Readings III. The Late Period, Berkeley-Los Angeles-London 
Lieven, A. von 2015: Antisocial gods?, [in:] Nyord, R., Ryholt, K. (Eds), Lotus and Laurel: Studies on Egyptian Language and Religion in Honour of Paul John Frandsen, CNIP 39, Copenhagen, 181-208

Massart, A. 1954: The Leiden Magical Papyrus, I 343 + I 345, Leiden

Mathieu, B. 1999: Les contes du Papyrus Westcar : une interpretation, EAO 15, 29-40

Meeks, D. 1996: Daily life of the Egyptian Gods, London

Moran, W.L. 1992: The Amarna Letters, Baltimore-London

Möller, G. 1961: Hieratische Lesestücke für den Akademischen Gebrauch. Zweites Heft. Literarische Texte des Neuen Reiches, Berlin

Müller, D. 1961: Ägypten und die griechischen Isis-Aretalogien, AAWL 53/1, Berlin

Münnich, M. 2013: The God Resheph in the Ancient Near East, Tübingen

Nunn, J.F. 1996: Ancient Egyptian Medicine, London

Nyord, R. 2009: Breathing Flesh: Conceptions of the Body in the Ancient Egyptian Coffin Texts, CNIP 37, Copenhagen

Ockinga, B. 1983: The Burden of Kha-kheperre-sonbu, JEA 69, 88-95

O'Connor, D.B. 2015: An Expanding Worldview: Conquest, Colonization, and Coexistence, [in:] Oppenheim, A., Arnold, D., Yamamoto, K. (Eds), Ancient Egypt Transformed: The Middle Kingdom, New York, 160-163

Osing, J., Rosati, G. 1998: Papiri geroglifici e ieratici da Tebtynis, Firenze

Parkinson, R. 1997a: The Tale of Sinuhe and Other Ancient Egyptian Poems, 19401640 BC, Oxford

Parkinson, R.B. 1997b: The Text of Khakheperreseneb: New Readings of EA 5645, and an Unpublished Ostracon, JEA 83, 55-68

Piankoff, A. 1942: Le livre du jour et de la nuit avec un chapitre sur l'écriture énigmatique, BiEtud 13, Le Caire

Piankoff, A., Rambova, N. 1957: Mythological Papyri, Texts, BollSer XL/3, New York

Quack, J.F. 1992: Studien zur Lehre für Merikare, GOF IV/23, Wiesbaden

Quirke, S. 2004: Egyptian Literature 1800 BC: Questions and Readings, GHP Egyptology 2, London

Quirke, S. 2013: Going out in Daylight: prt $m$ hrw. The Ancient Egyptian Book of the Dead: Translation, Sources, Meanings, GHP Egyptology 20, London

Raven, M. 2012: Egyptian Magic: The Quest for Thoth's Book of Secrets, Cairo

Redford, D. 1984: Akhenaten, the Heretic King, Cairo

Resche, R. 2016: Le papyrus médical Edwin Smith: chirurgie et magie en Egypte antique, Paris

Ritner, R. 1993: The Mechanics of Ancient Egyptian Magical Practice, SAOC 54, Chicago

Ritner, R. 2009: The Libyan Anarchy: Inscriptions from Egypt's Third Intermediate Period, Atlanta

Roberts, A. 2000: My Heart My Mother. Death and Rebirth in Ancient Egypt, Rottingdean Sadek, A. 1987: Popular Religion in Egypt during the New Kingdom, Ḧ̈B 27, Hildesheim Schneider, T. 2013: Ancient Egypt Investigated: 101 Important Questions and Intriguing Answers, London-New York 
Stevens, A. 2006: Private Religion at Amarna: The Material Evidence, Oxford Strandburg, A. 2009: The Gazelle in Ancient Egyptian Art. Image and Meaning, USE 6, Uppsala

Strouhal, E., Vachala, B., Vymazalová, H. 2014: The Medicine of the Ancient Egyptians. Surgery, Gynecology, Obstetrics, and Paediatrics, Cairo-New York

Szpakowska, K. 2003: Behind Closed Eyes. Dreams and Nightmares in Ancient Egypt, Swansea

Troy, L. 2015: How to Treat a Lady: Reflections on the 'notorious' P. Leiden I 371, [in:] Nyord, R., Ryholt, K. (Eds), Lotus and Laurel: Studies on Egyptian Language and Religion in Honour of Paul John Frandsen, CNIP 39, Copenhagen, 403-418

Verner, M., Callender, V., Strouhal, E. 2002: Djedkare's Family Cemetery, Abusir 6, Prague

Vernus, P. 1979: Un décret de Thoutmosis III relatif à la santé publique (P. Berlin 3049, $v^{0}$ XVIII-XIX), Orientalia 48/2, 176-184

Ward, W.A. 1980: Egypto-Semitic $m r$, "be better, strong", UgForsch 12, 357-360

Wente, E. 1967: Late Ramesside Letters, SAOC 33, Chicago

Wente, E. 1975-1976: A Misplaced Letter to the Dead, OLP 6/7, 595-600

Willems, H. 1996: The Coffin of Heqata (Cairo JdE 36418). A Case Study of Egyptian Funerary Culture of the Early Middle Kingdom, OLA 70, Leuven

Willems, H. (Ed.) 2001: Social Aspects of Funerary Culture in the Egyptian Old and Middle Kingdoms: Proceedings of the International Symposium held at Leiden University 6-7 June, 1996, OLA 103, Leuven-Paris

Wilson, P. 1997: A Ptolemaic Lexikon. A Lexicographical Study of the Texts in the Temple of Edfu, OLA 78, Leuven

Yamazaki, N. (Ed.) 2003: Zaubersprüche für Mutter und Kind: Papyrus Berlin 3027, Achet. Schriften zur Ägyptologie B 2, Berlin

Žabkar, L. 1988: Hymns to Isis in her Temple at Philae, Hanover-London

Zandee, J. 1977: Death as an Enemy, according to Ancient Egyptian Conceptions, New York Ziegler, C. 2008: Queens of Egypt: From Hetepheres to Cleopatra, Monaco 


\section{ÉTUDES et TRAVAUX XXXI / 2018}

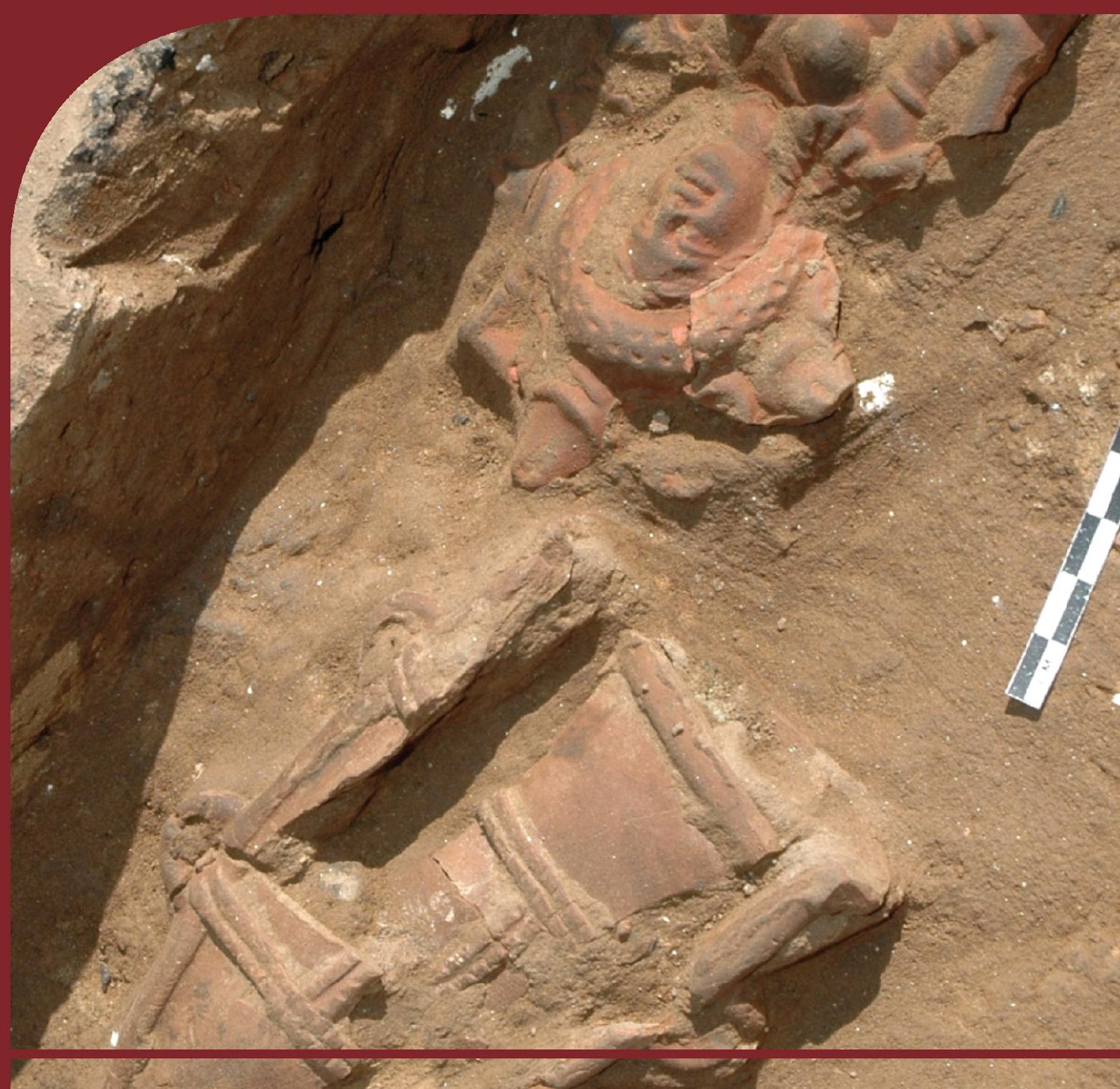

Institut des Cultures iyréditerranéennes et Oilentales FORIKSiO - de PAcadémie Polonaise des Sciences DS PA 


\section{COMITÉ DE RÉDACTION SCIENTIFIQUE}

Maciej Makowski - rédacteur en chef

Jadwiga Iwaszczuk - rédacteur

Mariusz Drzewiecki - sécretaire de la rédaction

Karol Myśliwiec - rédacteur thématique du volume

CONSEIL SCIENTIFIQUE DU JOURNAL

M. Kobusiewicz (IAE PAS, Warszawa), E. Laskowska-Kusztal (IMOC PAS, Warszawa)

D. Michaelides (University of Cyprus, Nicosia)

J.Ch. Moretti (IRAA-MOM, Université de Lyon 2/CNRS)

D. Raue (Ägyptisches Museum der Universität Leipzig), P. Reynolds (ICREA, España)

D. Welsby (British Museum, London)

\section{COMITÉ SCIENTIFIQUE DE LECTURE}

H.D. Baker (University of Toronto), P. Ballet (ArScAn-ESPRI, Université Paris Nanterre),

N. Beaux Grimal (IFAO, Cair/Collège de France, Paris), A. Dodson (University of Bristol),

L. Gabolde (CNRS), C. Gobeil (Egypt Exploration Society, London),

J. Holaubek (Institut für Ägyptologie, Wien), S. Ikram (American University in Cairo),

K. Innemée (Universiteit Leiden), Ch. Leitz (Universität Tübingen),

A. Loprieno-Gnirs (Universität Basel), Ch.E. Loeben (Museen für Kulturgeschichte, Hannover),

S. Ortisi (Universität München), A. Peignard-Giros (HiSoMA-MOM, Université de Lyon 2/CNRS),

E. Rova (Università Ca' Foscari Venezia), A. Sasson (San Diego Natural History Museum),

G. Schreiber (Eötvös Loránd University, Budapest), E. Teeter (University of Chicago),

Y. Tristant (Macquarie University, Sydney), V. Vaelske (independent researcher),

V.W.J. van Gerven Oei (independent researcher), H. Vymazalová (Charles University, Prague),

K. Winther-Jacobsen (Danish Institute at Athens),

J.A. Ostrowski, E. Papuci-Władyka, J. Śliwa (IA JU, Kraków),

R. Czerner (WUST, Wrocław), A. Ćwiek (IA AMU, Poznań),

K. Domżalski (IAE PAS, Warszawa), M. Pinker (FOS UW, Warszawa),

Ł. Niesiołowski-Spanò (IH UW, Warszawa), M. Gawlikowski (PCMA UW, Warszawa), K.O. Kuraszkiewicz (DE FOS UW, Warszawa), M. Barwik, P. Dyczek, W. Godlewski,

S. Rzepka, J. Żelazowski, A. Niwiński (IA UW, Warszawa)

\section{RÉDACTION TECHNIQUE}

Maciej Makowski, Jadwiga Iwaszczuk

CORRECTION LINGUISTIQUE

Jo Harper 
ÉTUDES et TRAVAUX

XXXI 
INSTYTUT KULTUR ŚRÓDZIEMNOMORSKICH I ORIENTALNYCH POLSKIEJ AKADEMII NAUK

\title{
STUDIA i PRACE
}

XXXI

\author{
gO IKŚiO \\ ESA PAN \\ WARSZAWA \\ 2018
}


INSTITUT DES CULTURES MÉDITERRANÉENNES ET ORIENTALES DE L'ACADÉMIE POLONAISE DES SCIENCES

\section{ÉTUDES et TRAVAUX}

XXXI

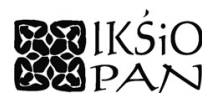

VARSOVIE

2018 
Publication scientifique financée dans le cadre du programme du Ministre de la Science et de l'Éducation Supérieure « Programme National de Développement de l'Humanistique » pour les années 2016-2021 (projet $n^{\circ} 3 \mathrm{bH} 15009983$ )

\title{
Harodowy PROGRAM ROZWOJU HUMANISTYKI
}

\author{
Copyright $($ ) \\ Instytut Kultur Śródziemnomorskich i Orientalnych PAN \\ et les Auteurs \\ Warszawa 2018
}

ISSN 2084-6762

(avant $2011: 0079-3566$ )

e-ISSN 2449-9579

Version première en papier, imprimée en Pologne - 150 copies

Version électronique accessible sur http://www.etudesettravaux.iksiopan.pl

Édition: Polskie Towarzystwo Historyczne et Wydawnictwo Neriton, Warszawa

Conception générale de couverture : J. Iwaszczuk Photo de couverture : P. Moser (C) Schweizerisches Institut für Ägyptische Bauforschung und Altertumskunde in Kairo

(terre cuites d'Aswan/Syene) 


\section{Table des matières}

KAROL MYŚLIWIEC

$(E T=E t u d T r a v / 50) \times 30$

HASSAN Aglan

Hatshepsut and the Apis Race: New Quartzite Relief Fragments

from Dra' Abu el-Naga

Amgad Joseph

Divine Wrath in Ancient Egypt

Amgad Joseph

Pain Infliction, Inflictors and Healers in Egyptian Religious, Magical

and Literary Perceptions

MirosŁaW BarwiK

New Dipinti in the Birth Portico of the Hatshepsut Temple at Deir el-Bahari

KrzyszTOF BorysŁaWsKi, ANNA NiwiŃSKA, ANDRZEJ NiwiŃSKI,

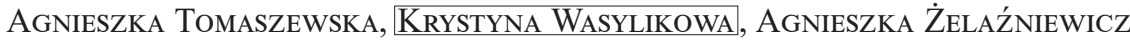

A Bulb of Narcissus on the Egyptian Mummy from University

of Wrocław Collection

LINDA CHAPON

Some Reliefs Representing the King in the Heb Sed Robe Discovered in the Henket-Ankh

Philippe Guillaume

Debunking the Latest Scenario on the Rise of the Pork Taboo

Mariola Hepa

A Clay Gladius Scabbard from Area 13c in the Ancient Roman Town of Syene

Emanuele E. Intagliata

Pinpointing Unrest at Palmyra in Early Islamic Period. The Evidence from Coin Hoards and Written Sources 
KATARZYNA KAPIEC

The Sacred Scents: Examining the Connection Between the ' $n t j w$ and $s f \underline{t}$ in the Context of the Early Eighteenth Dynasty Temples

DOMINIKA MAJCHRZAK

Remarks on the Iconographic Motif of the Birdman in Mesopotamian Glyptic Art of the Third Millennium BC

KAROLINA PAWLIK

Stone Artefacts from Late Roman Occupation Phases in Nea Paphos

ABRÉVIATIONS 
THE VOLUME IS PUBLISHED TO CELEBRATE

THE $50^{\text {TH }}$ ANNIVERSARY

OF THE

ÉTUDES ET TRAVAUX

ESTABLISHED IN 1966 